INEEL/EXT-98-01178

Rev. 2

October 1999

\title{
SCDAP/RELAP5 Modeling of
} Movement of Melted Material Through Porous Debris in Lower Head

L. J. Siefken 


\title{
SCDAP/RELAP5 Modeling of Movement of Melted Material Through Porous Debris in Lower Head
}

\author{
L. J. Siefken
}

Published October 1999

\section{Idaho National Engineering and Environmental Laboratory Idaho Falls, Idaho 83415}

Prepared for

Division of Systems Technology Office of Nuclear Regulatory Research

U.S. Nuclear Regulatory Commission

Washington, DC 20555-0001

NRC Job Code W6095 


\begin{abstract}
A model is described for the movement of melted metallic material through a ceramic porous debris bed. The model is designed for the analysis of severe accidents in LWRs, wherein melted core plate material may slump onto the top of a porous bed of relocated core material supported by the lower head. The permeation of the melted core plate material into the porous debris bed influences the heatup of the debris bed and the heatup of the lower head supporting the debris. A model for mass transport of melted metallic material is applied that includes terms for viscosity and turbulence but neglects inertial and capillary terms because of their small value relative to gravity and viscous terms in the momentum equation. The relative permeability and passability of the porous debris are calculated as functions of debris porosity, particle size, and effective saturation. An iterative numerical solution is used to solve the set of nonlinear equations for mass transport. The effective thermal conductivity of the debris is calculated as a function of porosity, particle size, and saturation. The model integrates the equations for mass transport with a model for the two-dimensional conduction of heat through porous debris. The integrated model has been implemented into the SCDAP/RELAP5 code for the analysis of the integrity of LWR lower heads during severe accidents. The results of the model indicate that melted core plate material may permeate in about $120 \mathrm{~s}$ to the bottom of a $1 \mathrm{~m}$ deep hot porous debris bed supported by the lower head. The presence of the relocated core plate material at the bottom of the debris bed decreases the thermal resistance of the interface between the debris bed and the lower head.
\end{abstract}

This report is a revision of the report with the identifier of INEEL/EXT-98-01178 REV 1, entitled "SCDAP/RELAP5 Modeling of Movement of Melted Material Through Porous Debris in Lower Head." 


\section{CONTENTS}

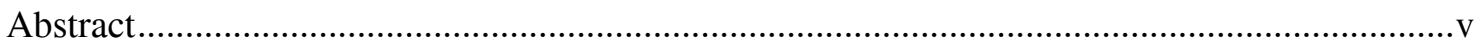

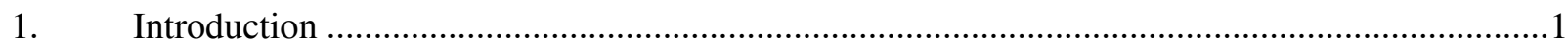

2. Models for Movement of Material in Porous Debris....................................................................3

3. Effects of Material Movement on Debris Bed Heat Transfer.....................................................7

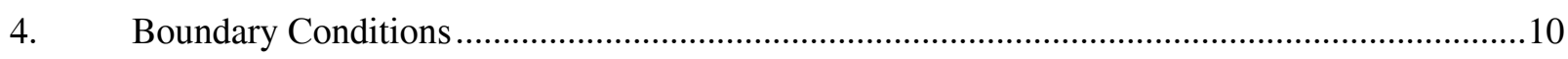

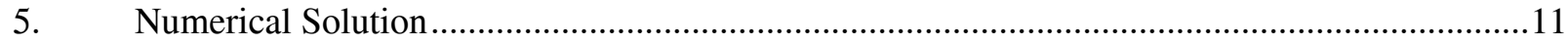

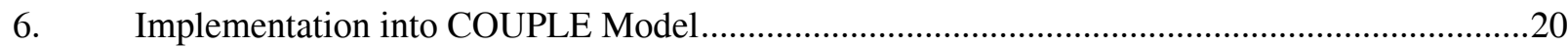

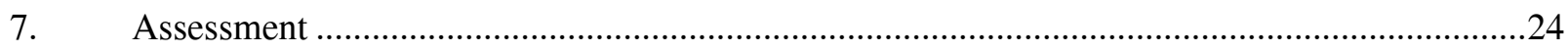

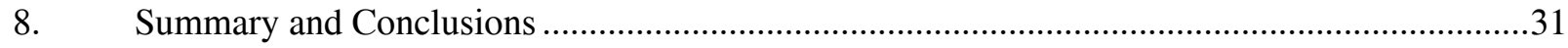

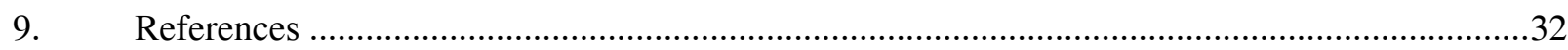

\section{FIGURES}

Figure 1-1. Schematic of system represented by COUPLE model (particle size of debris greatly

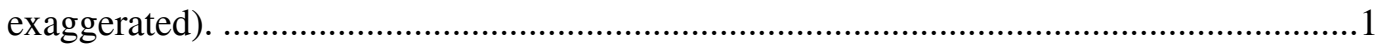

Figure 1-2. Previous modeling of liquefied material within porous debris bed. ................................2

Figure 1-3. Extension in modeling of liquefied material within porous debris bed.............................2

Figure 4-1. Schematic of material movement occurring when core plate melts and lower head supports ceramic porous debris........................................................... 11

Figure 5-1. Coordinate system for numerical solution .............................................................. 12

Figure 7-1. Schematic and nodalization diagram of assessment problem.......................................25

Figure 7-2. Calculated transient distribution of stainless steel in debris bed ....................................26

Figure 7-3. Calculated transient distribution in superficial velocity of stainless steel

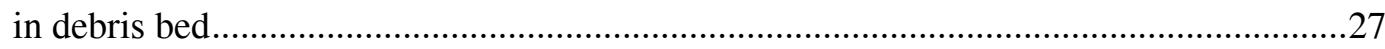

Figure 7-4. Calculated transient temperature distribution in debris bed along its centerline ..............28

Figure 7-5. Transient temperature of inner surface of lower head at location $0.5 \mathrm{~m}$ above

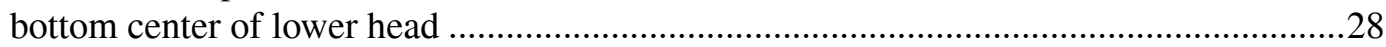

Figure 7-6. Temperature histories for three cases of inner surface of lower head at location $0.5 \mathrm{~m}$ above bottom center of lower head.... .28

\section{TABLES}

Table 5-1. Characteristics and properties for debris and melted stainless steel

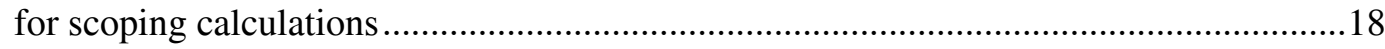

Table 5-2. Values of coefficients in Equation (5-8) for two representative cases .............................19

Table 5-3. Superficial velocities for two representative cases ........................................................19

Table 6-1. Variables added to COUPLE data base for modeling of flow

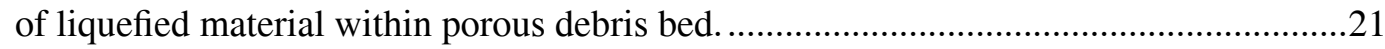

Table 6-2. User-defined variables added to data base for modeling of flow of liquefied material within porous debris bed. 
Table 6-3. Extensions to existing COUPLE subroutines for modeling flow of

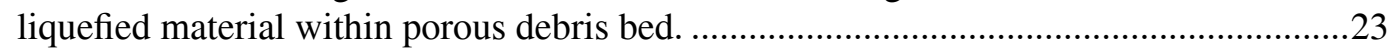

Table 7-1. Initial conditions and boundary conditions for assessment problem..............................24

Table 7-2. Effect of level of debris saturation on thermal conductivity of debris............................29

Table 7-3. Study of sensitivity of calculated results to accuracy criterion ........................................29

Table 7-4. Sensitivity of calculated results to rate of slumping and particle size ..............................30 


\section{Introduction}

In the event of a severe accident in a Light Water Reactor (LWR), particles of a ceramic mixture of $\mathrm{UO}_{2}$ and $\mathrm{ZrO}_{2}$ may stack in the lower head of the reactor vessel and form a porous debris bed. The context of the porous debris bed is shown in Figure 1-1. The slumping of jets of a mixture of molten $(\mathrm{U}, \mathrm{Zr}) \mathrm{O}_{2}$ into a pool of water in the lower head is an example of a reactor core degradation event that may occur during a severe accident and result in the configuration of material shown in Figure 1-1. If the severe accident is not terminated, then eventually core plate material may melt and slump onto the top of the bed of ceramic particles. The core plate is generally composed of stainless steel and thus melts at a much lower temperature than the particles of $(\mathrm{U}, \mathrm{Zr}) \mathrm{O}_{2}(1700 \mathrm{~K}$ versus $\sim 3000 \mathrm{~K})$. The subsequent heatup of the debris bed and lower head is a function of the extent to which the melted core plate permeates into the bed of (U, $\mathrm{Zr}) \mathrm{O}_{2}$ particles. This report describes a model for calculating the permeation of the melted core plate material into the porous debris bed and describes the implementation of this model into the existing model in the SCDAP/RELAP5 code $^{1}$ for calculating the heatup of the debris bed and lower head supporting the debris bed.

The COUPLE model in SCDAP/RELAP5 calculates the heatup of the lower head and the debris that it supports. The system that the COUPLE model is designed to analyze is shown in Figure 1-1. Previously

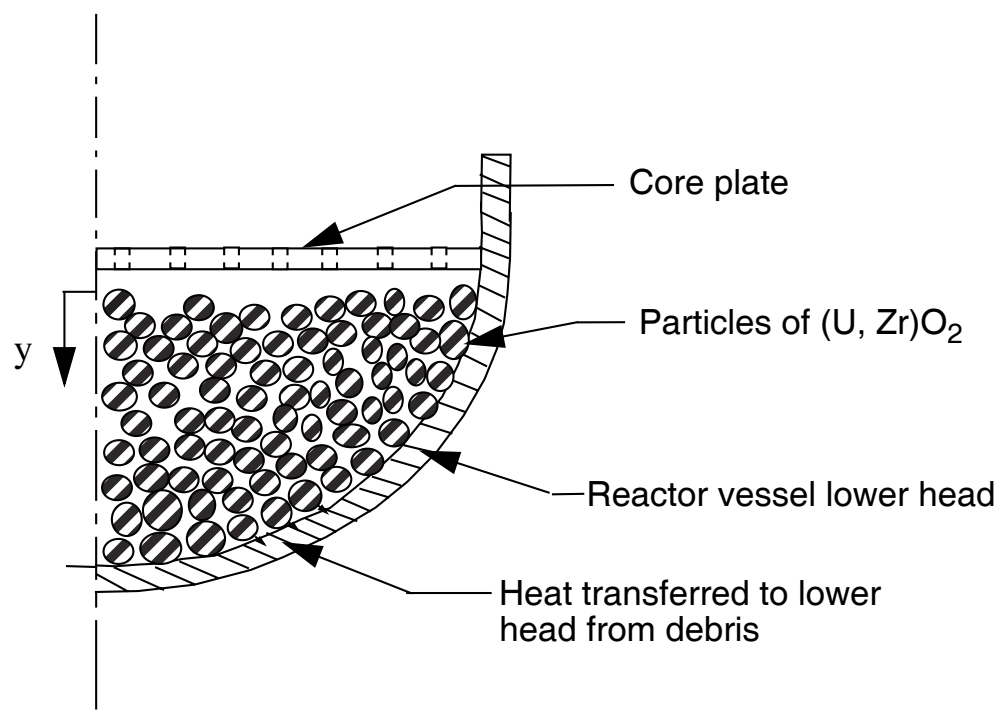

Figure 1-1. Schematic of system represented by COUPLE model (particle size of debris greatly exaggerated).

the COUPLE model could not calculate the movement of melted material. A schematic of the previous modeling capability with respect to melted material is shown in Figure 1-2. The schematic of modeling capability added to the COUPLE model is shown in Figure 1-3.

This report is organized as follows. Section 2 describes the model applied to calculate the movement of liquefied core plate material through the interstices in a matrix of porous $(\mathrm{U}, \mathrm{Zr}) \mathrm{O}_{2}$ debris. Section 3 describes the effect of liquefied material movement on debris bed heat transfer. Section 4 describes the 


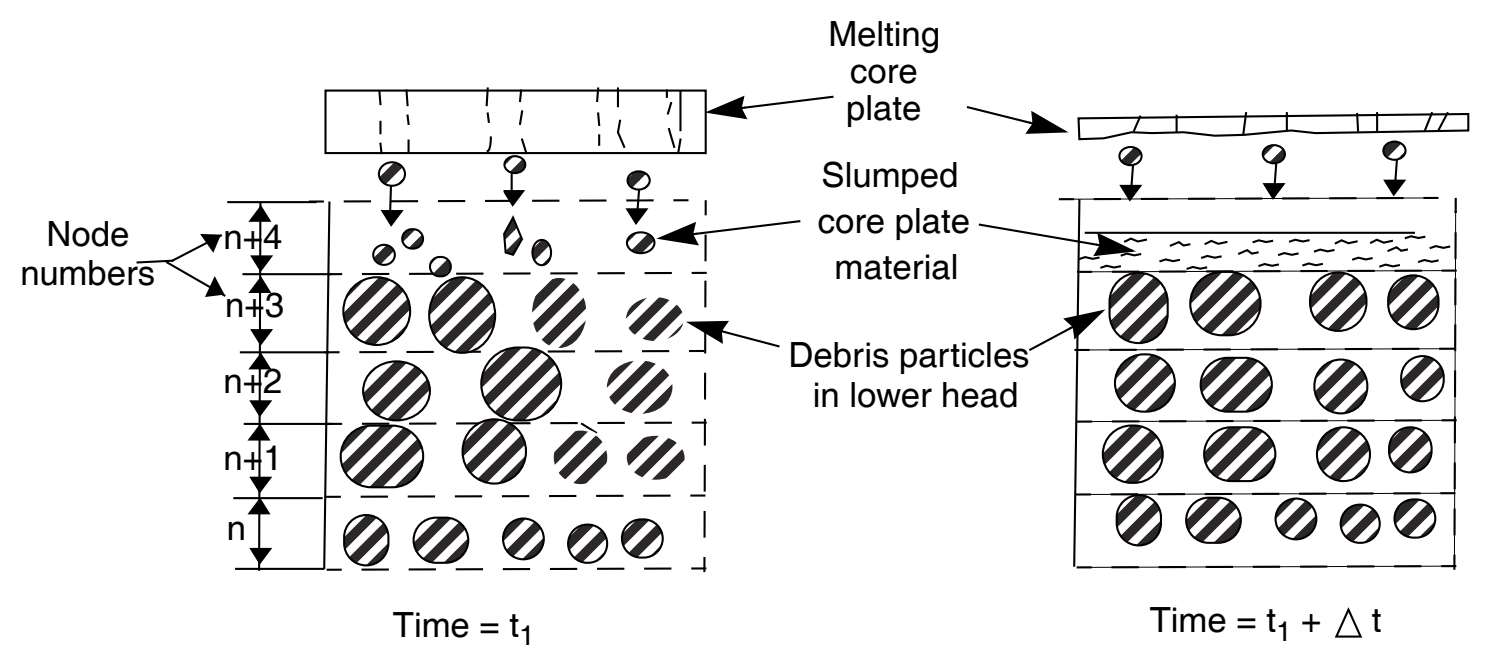

Figure 1-2. Previous modeling of liquefied material within porous debris bed.

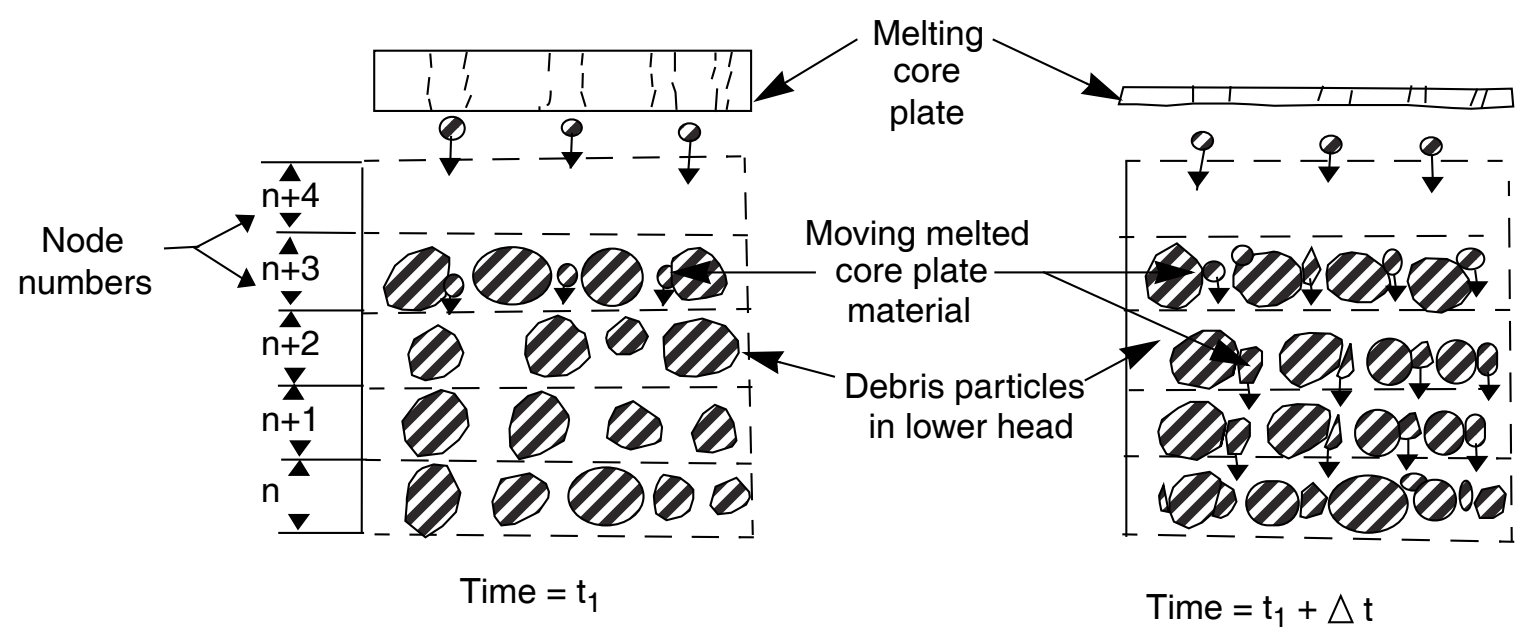

Figure 1-3. Extension in modeling of liquefied material within porous debris bed.

boundary conditions for porous debris with liquefied material slumping onto it and liquefied material permeating to the bottom of it. The numerical solution for the processes being modeled are described in Section 5 and the basic features of its implementation are described in Section 6. Section 7 presents the testing and assessing of the implemented models. The conclusions are presented in Section 8. The references are presented in Section 9. 


\section{Models for Movement of Material in Porous Debris}

This section describes the model to be applied for calculating the movement liquefied core plate material through the interstices in a matrix of porous material. The system to be analyzed has been previously shown in Figure 1-3. The movement of the liquefied material is driven by several forces, including gravity, capillary force, and pressure gradient. Resistances to movement are caused by viscous forces, turbulence and form losses due to a continuous contraction and expansion of flow areas as the liquefied material flows through the porous debris. The resistances to movement increase with the velocity of the moving material. The balancing of the forces driving the movement of the liquefied material with the forces resisting the movement results in a conservation of momentum equation for the liquefied material.

The following assumptions are applied to simplify the modeling in a manner that maintains an accuracy of solution of the same order of magnitude as the uncertainties of governing material properties and debris behavior.

1. The porous medium is composed only of $(\mathrm{U}, \mathrm{Zr}) \mathrm{O}_{2}$ particles.

2. The material permeating the porous medium is composed only of stainless steel.

3. Stainless steel does not chemically react with $(\mathrm{U}, \mathrm{Zr}) \mathrm{O}_{2}$.

4. The (U, $\mathrm{Zr}) \mathrm{O}_{2}$ particles do not melt.

5. The permeating stainless steel is in thermal equilibrium with the $(\mathrm{U}, \mathrm{Zr}) \mathrm{O}_{2}$ particles it contacts.

6. Stainless steel does not permeate through any location with a temperature less than the solidus temperature of stainless steel $(1671 \mathrm{~K})$.

7. Stainless steel does not permeate through any location with a temperature greater than the melting temperature of $(\mathrm{U}, \mathrm{Zr}) \mathrm{O}_{2}(\sim 3000 \mathrm{~K})$.

8. Gas does not flow through the porous debris bed.

9. Water is not present at any location with liquefied stainless steel.

10. Capillary forces are negligible.

11. The frictional drag on the liquefied stainless steel is balanced by the force of gravity with the result of quasi-steady flow of the liquefied material through the voids in the debris bed (acceleration of liquefied material and momentum flux are small compared to gravity).

12. The relative passability of the debris bed is equal to its relative permeability.

13. Liquefied stainless steel does not move in the radial direction; this assumption is based on the expectation of debris characteristics and extent of saturation that are almost uniform in the radial direction. 
14. The effect of a wall (lower head) on the movement of the liquefied stainless steel is negligible.

In general, the assumptions are consistent with the expected behavior of the core plate and the expected characteristics of lower plenum debris. The omission of the inertial and capillary terms in the momentum equation is based on order of magnitude analyses; the results of these analyses are presented at the end of the section on numerical solution (Section 5), where results are calculated for representative cases.

Taking into account the above assumptions, the conservation of momentum equation for the liquefied material is given by the equation ${ }^{2,3}$

$\frac{\mu_{1} \mathrm{j}}{\mathrm{k}_{1} \mathrm{k}}+\frac{\rho_{1} \mathrm{j}^{2}}{\mathrm{~m}_{1} \mathrm{~m}}=\rho_{1} \mathrm{~g}$

where

$$
\begin{array}{lll}
\mu_{1} & = & \text { dynamic viscosity of liquefied material }(\mathrm{kg} / \mathrm{m} \cdot \mathrm{s}), \\
\mathrm{j} & = & \text { superficial velocity of liquefied material }(\mathrm{m} / \mathrm{s}), \\
\mathrm{k} & = & \text { Darcy permeability }\left(\mathrm{m}^{2}\right), \\
\mathrm{k}_{1} & = & \text { relative permeability (unitless), } \\
\mathrm{m} & = & \text { passability of debris bed }(\mathrm{m}), \\
\mathrm{m}_{1} & = & \text { relative passability of debris bed }(\text { unitless }), \\
\rho_{1} & = & \text { density of liquefied material }\left(\mathrm{kg} / \mathrm{m}^{3}\right), \\
\mathrm{g} & = & \text { acceleration of gravity }\left(9.8 \mathrm{~m} / \mathrm{s}^{2}\right) .
\end{array}
$$

The second term of the above equation is the turbulent drag counterpart to the viscous drag represented by the first term.

The Darcy permeability is calculated by the equation

$$
k=\frac{\varepsilon^{3} D_{P}^{2}}{150(1-\varepsilon)^{2}}
$$

where 
$\varepsilon \quad=\quad$ porosity of the debris bed (unitless),

$\mathrm{D}_{\mathrm{P}} \quad=\quad$ diameter of particles in debris bed $(\mathrm{m})$.

The passability of the debris bed is calculated by the equation

$\mathrm{m}=\frac{\varepsilon^{3} \mathrm{D}_{\mathrm{P}}}{1.75(1-\varepsilon)}$

In general the relative passability is less than the relative permeability, but they are assumed to be equal for this analysis. ${ }^{4}$ Thus,

$\mathrm{m}_{1}=\mathrm{k}_{1}$

The relative permeability is a function of the effective saturation of the debris bed and the Darcy permeability. The relative permeability is calculated by the equation ${ }^{2}$

$\mathrm{k}_{1}=\mathrm{S}_{\mathrm{e}}^{3}, \mathrm{~S}_{\mathrm{e}}>0$

$\mathrm{k}_{1}=0, \mathrm{~S}_{\mathrm{e}} \leq 0$

where

$\mathrm{S}_{\mathrm{e}} \quad=\quad$ effective saturation of debris bed (unitless).

The effective saturation is calculated by the equation ${ }^{2}$

$S_{e}=\frac{S-S_{r}}{1-S_{r}}$

where

$$
\begin{array}{ll}
\mathrm{S} \quad=\quad \begin{array}{l}
\text { true saturation of debris bed; volume fraction of liquefied material in pores of } \\
\text { debris bed (unitless) },
\end{array} \\
\mathrm{S}_{\mathrm{r}} \quad=\quad \text { residual saturation of debris bed (unitless). }
\end{array}
$$

The residual saturation, $S_{r}$, is a function of the surface tension of the liquid and of the degree of wetting of the solid material by the liquefied material. Reference ${ }^{2}$ provides an empirical equation for calculating residual saturation that is appropriate for debris resulting from the disintegration of nuclear reactor cores. This equation is 


$$
\mathrm{S}_{\mathrm{r}}=\left\{\begin{array}{cl}
\frac{1}{86.3}\left[\frac{\gamma \cos (\theta)}{\mathrm{k} \rho_{1} \mathrm{~g}}\right]^{0.263} & ; 0 \leq \theta \leq 90^{\circ} \\
0 & ; 90^{\circ}<\theta \leq 180^{\circ}
\end{array}\right.
$$

where

$$
\begin{array}{lll}
\gamma & = & \text { surface tension of the liquid }(\mathrm{N} / \mathrm{m}), \\
\theta & = & \text { wetting contact angle (degrees). }
\end{array}
$$

In the case of liquefied material that does not wet the solid material $\left(90^{\circ}<\theta<180^{\circ}\right)$, the residual saturation is equal to zero. An example of such a system is a debris bed composed of ( $\mathrm{U}, \mathrm{Zr}) \mathrm{O}_{2}$ and liquefied stainless steel. ${ }^{2}$ In this case, bulk motion occurs at a relatively low values of bed saturation.

The conservation of mass equation is applied to obtain the relation of the rate of change with time of the local saturation of the debris bed to the local velocity of the liquefied debris. The result is the equation

$$
\frac{\partial S}{\partial t}=-\frac{\partial j}{\partial y} \quad\left(T_{s}<T_{\text {sol }}\right)
$$

where

$$
\begin{array}{lll}
\mathrm{t} & = & \text { time }(\mathrm{s}), \\
\mathrm{y} & = & \text { spatial coordinate that defines elevation (defined in Figure } 1-1)(\mathrm{m}) .
\end{array}
$$

Equations (2-1) and (2-8) are a set of two equations for solving for the variables $\mathrm{j}$ and $\mathrm{S}$. The terms $\mathrm{k}_{1}$ and $m_{1}$ in Equation (2-1) are a function of $S$ and thus contribute to the nonlinearity of the set of equations. Although the momentum equation in the model described in Reference 2 omits the turbulent term in Equation (2-1), a hand calculation for a possible debris bed condition indicated that for a saturated debris bed the omission of the turbulent term would result in a factor of three overprediction of the velocity of the liquefied material. These calculations are presented at the end of the section on the numerical solution (Section 5). So the turbulent term is being retained for the present model.

\section{Effects of Material Movement on Debris Bed Heat Transfer}

The movement of liquefied core plate material through the interstices in a porous debris bed results in the transport of energy within the debris bed. In addition, the movement of the liquefied material through the debris bed influences the thermal conductivity and heat capacity of the debris bed. As a result, the movement of liquefied material may have a significant influence on the temperature distribution within the debris bed. This section defines the change to be made to the heat transport equations in the COUPLE model $^{1}$ so as to account for the effect of material movement on temperature distribution. 
The COUPLE model calculates the transport of heat through a porous medium by the equation

$\left(\rho c_{v}\right)_{e} \frac{\partial T}{\partial t}=\frac{\partial}{\partial x}\left(K_{e} \frac{\partial T}{\partial x}\right)+\frac{\partial}{\partial y}\left(K_{e} \frac{\partial T}{\partial y}\right)+Q$

where

$$
\begin{array}{lll}
\left(\rho \mathrm{c}_{\mathrm{v}}\right)_{\mathrm{e}} & = & \left(1-\varepsilon_{\mathrm{h}}\right)\left(\rho \mathrm{c}_{\mathrm{v}}\right)_{\mathrm{m}}, \\
\rho & = & \text { density }\left(\mathrm{kg} / \mathrm{m}^{3}\right), \\
\mathrm{c}_{\mathrm{v}} & = & \text { constant volume specific heat }(\mathrm{J} / \mathrm{kg} \cdot \mathrm{K}), \\
\mathrm{K}_{\mathrm{e}} & = & \text { effective thermal conductivity }(\mathrm{W} / \mathrm{m} \cdot \mathrm{K}), \\
\mathrm{Q} & = & \text { volumetric heat generation rate }\left(\mathrm{W} / \mathrm{m}^{3}\right), \\
\mathrm{T} & = & \text { temperature of debris }(\mathrm{K}), \\
\varepsilon_{\mathrm{h}} & = & \text { heat conduction porosity of debris; } \varepsilon(1-\mathrm{S})(\mathrm{unitless}), \\
\mathrm{S} & = & \text { saturation of debris bed, } \\
\mathrm{x} & = & \text { spatial coordinate in horizontal direction }(\mathrm{m}), \\
\mathrm{y} & = & \text { spatial coordinate in vertical direction }(\mathrm{m}), \\
\mathrm{m} & = & \text { subscript indicating mixture of stainless steel and }(\mathrm{U}, \mathrm{Zr}) \mathrm{O}_{2} .
\end{array}
$$

The boundary conditions for equation (3-1) are defined by the code user. Boundary conditions are defined for the bottom and top surfaces, and left and right surfaces of the region being represented by the COUPLE model. The boundary conditions at these surfaces can be either adiabatic surface or convection and radiative heat transfer to fluid. ${ }^{1}$ For the outer surface of a reactor vessel lower head submerged in water, the convective heat transfer is calculated using the Cheung model. ${ }^{5}$ For other surfaces, the convective heat transfer is calculated by the RELAP5 convective heat transfer models. ${ }^{6}$

The above equation models heat transport through debris by conduction and radiation. To account for the transport of heat by the movement of liquefied material, the $\mathrm{Q}$ term in the above equation will be replaced by the term

$$
\mathrm{Q}_{\mathrm{N}}=\mathrm{Q}+\mathrm{Q}_{\mathrm{T}}
$$

where 


$$
\begin{array}{lll}
\mathrm{Q}_{\mathrm{N}} & = & \text { net volumetric heat generation rate }\left(\mathrm{W} / \mathrm{m}^{3}\right), \\
\mathrm{Q}_{\mathrm{T}} & = & \text { effective heat generation due to movement of liquefied material }\left(\mathrm{W} / \mathrm{m}^{3}\right) .
\end{array}
$$

The variable $\mathrm{Q}_{\mathrm{T}}$ in the above equation is a function of the rate of flow of the liquefied material and the temperature gradient in the debris bed. Taking into account the instant thermal equilibrium of the liquefied material with the debris it contacts (Assumption \#5 in Section 2) this variable is calculated by the equation

$$
\mathrm{Q}_{\mathrm{T}}=-\rho_{1} \mathrm{c}_{\mathrm{p}} \mathrm{j} \frac{\partial \mathrm{T}}{\partial \mathrm{y}}
$$

where

$$
\begin{array}{lll}
\mathrm{j} & = & \text { superficial velocity of liquefied material }(\mathrm{m} / \mathrm{s}), \\
\rho_{1} & = & \text { density of liquefied material }\left(\mathrm{kg} / \mathrm{m}^{3}\right), \\
\mathrm{c}_{\mathrm{p}} & = & \text { heat capacity of liquefied material }(\mathrm{J} / \mathrm{kg} \cdot \mathrm{K}), \\
\frac{\partial \mathrm{T}}{\partial \mathrm{y}} & = & \begin{array}{l}
\text { temperature gradient in debris bed in direction of movement of liquefied } \\
\text { material }(\mathrm{K} / \mathrm{m}) .
\end{array}
\end{array}
$$

The movement of liquefied material through the interstices of a porous debris bed influences the effective thermal conductivity of the debris bed. The effective thermal conductivity is calculated by the equation

$\mathrm{k}_{\mathrm{e}}=\mathrm{k}_{\mathrm{ec}}+\mathrm{k}_{\mathrm{r}}$

where

$$
\begin{array}{lll}
\mathrm{k}_{\mathrm{e}} & = & \text { effective conductivity }(\mathrm{W} / \mathrm{m} \cdot \mathrm{K}), \\
\mathrm{k}_{\mathrm{ec}} & = & \text { effective conductivity (conduction only) }(\mathrm{W} / \mathrm{m} \cdot \mathrm{K}), \\
\mathrm{k}_{\mathrm{r}} & = & \text { radiative conductivity }(\mathrm{W} / \mathrm{m} \cdot \mathrm{K}) .
\end{array}
$$

The Imura-Takegoshi ${ }^{7}$ model for thermal conductivity is combined with the Vortmeyer ${ }^{8}$ radiation model.

The Imura-Takegoshi model in equation form is given as follows:

$$
\mathrm{k}_{\mathrm{ec}}=\left[\Psi+\frac{1-\Psi}{\phi+\frac{1-\phi}{v}}\right] \mathrm{k}_{\mathrm{g}}
$$


$\phi=0.3 \varepsilon_{\mathrm{h}}^{1.6} v^{-0.044}$

$v=\frac{\mathrm{k}_{\mathrm{s}}}{\mathrm{k}_{\mathrm{g}}}$

$\Psi=\frac{\varepsilon_{\mathrm{h}}-\phi}{1-\phi}$

where

$$
\begin{array}{lll}
\mathrm{k}_{\mathrm{g}} & = & \text { thermal conductivity of vapor in pores }(\mathrm{W} / \mathrm{m} \cdot \mathrm{K}), \\
\mathrm{k}_{\mathrm{S}} & = & \text { thermal conductivity of mixture of stainless steel and }(\mathrm{U}, \mathrm{Zr}) \mathrm{O}_{2}(\mathrm{~W} / \mathrm{m} \cdot \mathrm{K}), \\
\varepsilon_{\mathrm{h}} & =\quad \text { porosity of debris for heat transfer calculations }=\varepsilon(1-\mathrm{S}) .
\end{array}
$$

The mixture thermal conductivity $\left(\mathrm{k}_{\mathrm{s}}\right)$ is calculated by the MATPRO function named ZUTCO1. ${ }^{9}$

The Vortmeyer model is given as

$\mathrm{k}_{\mathrm{r}}=4 \eta \sigma \mathrm{D}_{\mathrm{p}} \mathrm{T}^{3}$

where

$$
\begin{array}{lll}
\eta & = & \text { radiation exchange factor (user-defined value, with default value of } 0.8), \\
\sigma & = & \text { Stefan-Boltzmann constant } \mathrm{W} / \mathrm{m}^{2} \cdot \mathrm{K}^{4}\left(5.668 \times 10^{-8}\right), \\
\mathrm{D}_{\mathrm{p}} & = & \text { particle diameter }(\mathrm{m}), \\
\mathrm{T} & = & \text { temperature }(\mathrm{K}) .
\end{array}
$$

\section{Boundary Conditions}

This section describes the boundary conditions applied to the model for movement of liquefied core plate material through a ceramic porous debris bed below the core plate. A schematic of the boundary conditions for the model is shown in Figure 4-1. 


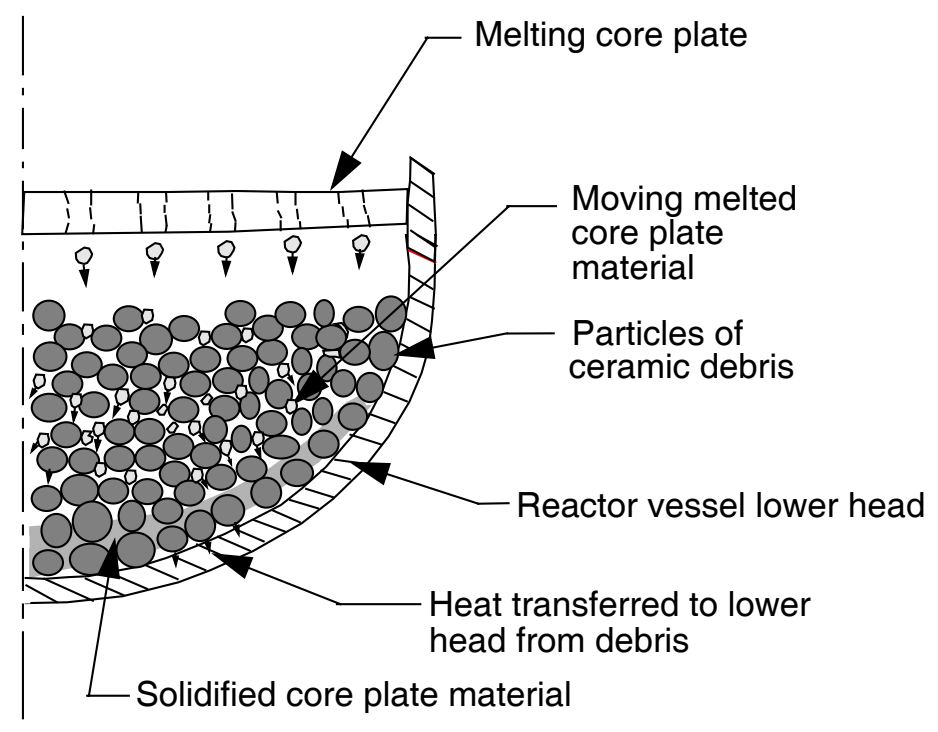

Figure 4-1. Schematic of material movement occurring when core plate melts and lower head supports ceramic porous debris.

For the top of the debris bed, the equation for the velocity of the liquefied material, namely Equation (2-1), is replaced by the equation

$$
\mathrm{j}_{\mathrm{T}}=\mathrm{G} / \rho_{1}
$$

where

$$
\begin{array}{ll}
\mathrm{j}_{\mathrm{T}} \quad & \begin{array}{l}
\text { superficial velocity of liquefied material at top surface of debris bed }(\mathrm{m} / \mathrm{s}), \\
\mathrm{G}
\end{array} \quad \begin{array}{l}
\text { rate of melting of structure above debris bed per unit of cross sectional area } \\
(\mathrm{kg} / \mathrm{s}) / \mathrm{m}^{2}
\end{array}
\end{array}
$$

The variable $\mathrm{G}$ is either calculated by the core plate mode ${ }^{10}$ or user-defined; the user selects the option.

The heat transfer at the bottom boundary of the debris bed is increased by the movement of melted core plate material to the bottom boundary. The heat transfer at the bottom boundary is proportional to the gap heat transfer coefficient defined for the interface of the debris and the lower head supporting the debris. This gap heat transfer coefficient is user-defined. For any location on the interface that has been contacted by liquefied material, the user-defined gap heat transfer coefficient is replaced by a gap heat transfer coefficient with a value of $10,000 \mathrm{~W} / \mathrm{m}^{2} \cdot \mathrm{K}$, which simulates the heat transfer across a gap filled with material with a relatively large thermal conductivity. 


\section{Numerical Solution}

An explicit, iterative scheme for numerical solution is used to solve for the distribution in velocity and debris bed saturation. The coordinate system and the nodalization for the numerical solution are shown in Figure 5-1. The debris bed is divided into a stack of control volumes. The control volumes are connected to each other with junctions. The extent of bed saturation is calculated for each control volume and the velocity of the liquefied material is calculated at each junction. The scheme for the numerical solution is based on the concept that the velocity gradient changes at a slower rate than the degree of bed saturation. In the first step for the first iteration, the change in bed saturation for each control volume is calculated using previous time step velocities at the junctions of the control volumes. Next, the end of time step velocity at each junction is calculated using the values for bed saturation calculated in the previous step. Next, the bed saturation in each central volume is calculated using the velocities just calculated for the end of the time step. If at any control volume the difference between the last two values calculated for bed saturation is greater than the tolerance for error in bed saturation, another iteration is performed. Subsequent iterations are performed until convergence is obtained at each control volume.

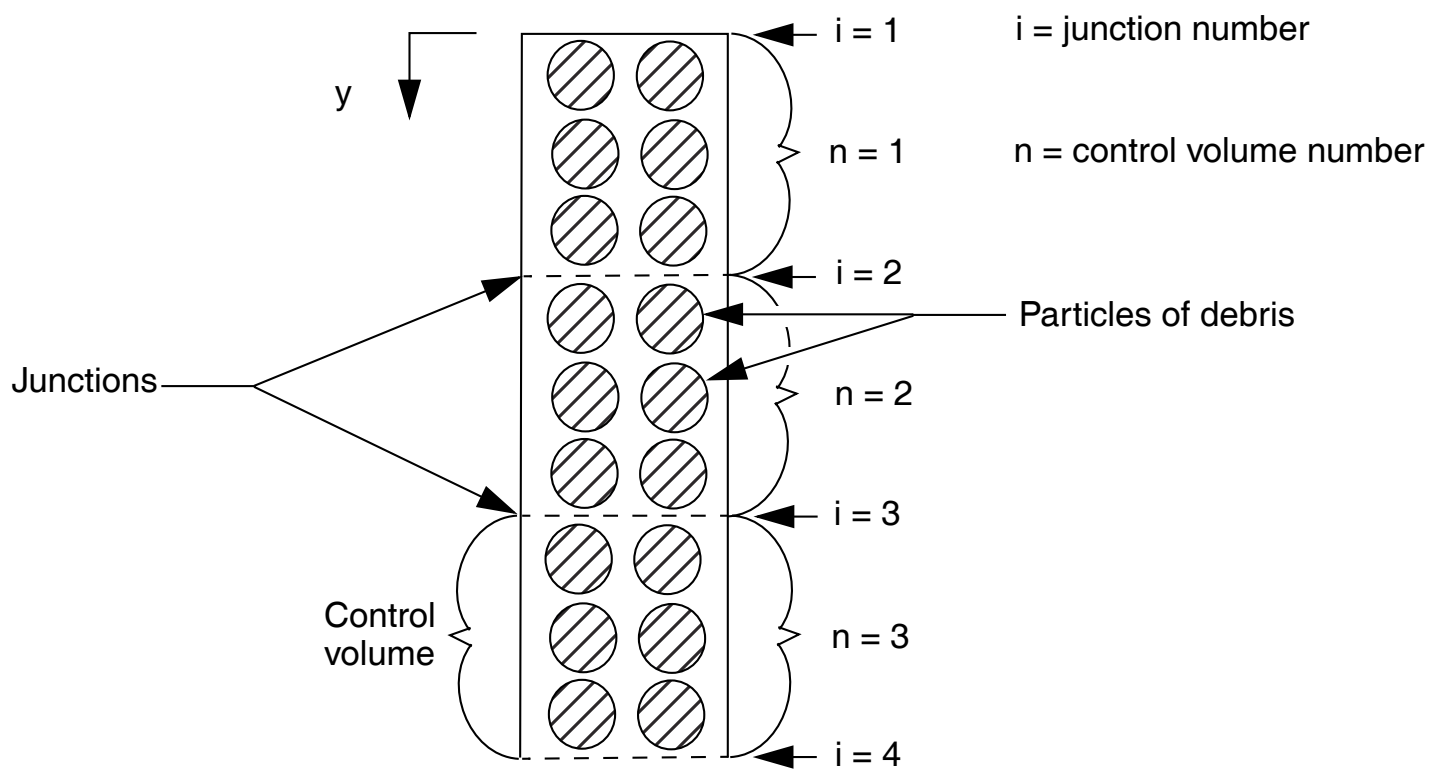

Figure 5-1. Coordinate system for numerical solution.

The equations in the numerical solution scheme are arranged as follows. First, a guess of the end of time step bed saturation is calculated using the equation

$S_{n}^{m+1}=S_{n}^{m}-\left[\frac{\left(j_{n p}^{m}-j_{n m}^{m}\right)}{\left(y_{n p}-y_{n m}\right)}\right] \Delta t$ 
where

$$
\begin{array}{lll}
\mathrm{m} & = & \text { time step number, } \\
\mathrm{S}_{\mathrm{n}}^{\mathrm{m}+1} & = & \text { bed saturation at control volume } \mathrm{n} \text { at end of time step, } \\
\mathrm{S}_{\mathrm{n}}^{\mathrm{m}} & = & \text { same as } \mathrm{S}_{\mathrm{n}}^{\mathrm{m}+1}, \text { but for start of time step, } \\
\mathrm{j}_{\mathrm{np}}^{\mathrm{m}} & = & \begin{array}{l}
\text { superficial velocity at start of time step of liquefied material at junction at } \\
\text { downwind side of control volume } \mathrm{n}(\mathrm{m} / \mathrm{s}),
\end{array} \\
\mathrm{j}_{\mathrm{nm}}^{\mathrm{m}} & = & \text { same as } \mathrm{j}_{\mathrm{np}}^{\mathrm{m}}, \text { but for junction at upwind side of control volume } \mathrm{n}(\mathrm{m} / \mathrm{s}), \\
\varepsilon & = & \text { porosity for mass transport calculations (unitless), } \\
\mathrm{y}_{\mathrm{np}} & = & \text { elevation of junction at downwind side of control volume } \mathrm{n}(\mathrm{m}), \\
\mathrm{y}_{\mathrm{nm}} & = & \text { elevation of junction at upwind side of control volume } \mathrm{n}(\mathrm{m}), \\
\Delta \mathrm{t} & = & \text { time step }(\mathrm{s}) .
\end{array}
$$

In the above equation, the control volumes are assumed to have uniform cross sectional areas.

Two categories of porosity are calculated at each control volume at each time step. One category of porosity, named the mass transport porosity, is used in the equations that calculate the flow of liquefied material. For this category, the volumes of liquid and gas are lumped together to represent the porosity. The other category of porosity, named the heat conduction porosity, is used in the equations that calculate the conduction of heat through the debris bed. For this category, the volumes of solid material and liquefied debris are lumped together.

The heat conduction porosity is related to the mass transport porosity by the equation

$\varepsilon_{\mathrm{h}}=\varepsilon\left(1-\mathrm{S}_{\mathrm{n}}^{\mathrm{m}+1}\right)$.

where

$$
\begin{array}{lll}
\varepsilon_{\mathrm{h}} & = & \text { heat conduction porosity (unitless), } \\
\varepsilon & = & \text { mass transport porosity (unitless), } \\
\mathrm{S}_{\mathrm{n}}^{\mathrm{m}+1} & = & \text { saturation of debris bed (unitless). }
\end{array}
$$

Next, the Darcy permeability and the passability of the debris bed are updated using the equations

$$
\mathrm{k}_{\mathrm{n}}=\frac{\varepsilon^{3} \mathrm{D}_{\mathrm{P}}^{2}}{150(1-\varepsilon)^{2}}
$$




$$
\mathrm{m}_{\mathrm{n}}=\frac{\varepsilon^{3} \mathrm{D}_{\mathrm{P}}}{1.75(1-\varepsilon)}
$$

where

$$
\begin{array}{lll}
\mathrm{k}_{\mathrm{n}} & = & \text { Darcy permeability of debris bed at control volume } \mathrm{n}\left(\mathrm{m}^{2}\right), \\
\mathrm{m}_{\mathrm{n}} & = & \text { passability of debris bed at control volume } \mathrm{n}(\mathrm{m}) .
\end{array}
$$

Then, the effective saturation of the debris bed at the end of the time step for each control volume is calculated using the equation

$\mathrm{S}_{\mathrm{en}}^{\mathrm{m}+1}=\frac{\mathrm{S}_{\mathrm{n}}^{\mathrm{m}+1}-\mathrm{S}_{\mathrm{r}}}{1-\mathrm{S}_{\mathrm{r}}}$

where

$$
\mathrm{S}_{\mathrm{en}}^{\mathrm{m}+1} \quad=\quad \text { effective saturation at control volume } \mathrm{n} \text { at end of time step. }
$$

The residual saturation, $S_{\mathrm{r}}$, is a function of material properties, namely wetting angle, surface tension, Darcy permeability, and liquid density; it is calculated using Equation (2-7).

Next, the relative permeability of the debris bed at the end of the time step for each control volume is calculated using the equation

$$
\mathrm{k}_{\ln }^{\mathrm{m}+1}=\left[\mathrm{S}_{\mathrm{en}}^{\mathrm{m}+1}\right]^{3}
$$

where

$$
\mathrm{k}_{\mathrm{ln}}^{\mathrm{m}+1}=\quad \text { relative permeability at control volume } \mathrm{n} \text { at end of time step. }
$$

The relative passability of the debris bed at the end of the time step for each control volume is calculated using the equation

$$
\mathrm{m}_{\mathrm{ln}}^{\mathrm{m}+1}=\mathrm{k}_{\mathrm{ln}}^{\mathrm{m}+1}
$$

where

$$
\mathrm{m}_{\ln }^{\mathrm{m}+1}=\quad \text { relative passability of debris bed at control volume } \mathrm{n} \text { at end of time step. }
$$


Next, the velocity of the liquefied material at each junction is calculated using Equation (2-1). For numerical solution, terms in this equation are combined as follows

$$
A\left[j_{i}^{m+1}\right]^{2}+B j_{i}^{m+1}+C=0
$$

where

$$
\begin{array}{lll}
\mathrm{j}_{\mathrm{i}}^{\mathrm{m}+1} & = & \text { superficial velocity at junction } \mathrm{i} \text { at end of time step }(\mathrm{m} / \mathrm{s}), \\
\mathrm{A} & =\frac{\rho_{1}}{\mathrm{~m}_{\mathrm{li}}^{\mathrm{m}+1} \mathrm{~m}_{\mathrm{i}}} \\
\mathrm{B} & =\frac{\mu_{1}}{\mathrm{k}_{\mathrm{li}}^{\mathrm{m}+1} \mathrm{k}_{\mathrm{i}}} \\
\rho_{1} & =\rho_{1} \mathrm{~g} \\
\mu_{1} & = & \text { density of liquefied debris }\left(\mathrm{kg} / \mathrm{m}^{3}\right), \\
\mathrm{g} & = & \text { acceleration of gravity }\left(9.8 \mathrm{~m} / \mathrm{s}^{2}\right), \\
\mathrm{m}_{\mathrm{li}}^{\mathrm{m}+1} & = & \text { relative passability at junction } \mathrm{i} \text { at end of time step (unitless), } \\
\mathrm{k}_{\mathrm{li}}^{\mathrm{m}+1} & = & \text { relative permeability at junction } \mathrm{i} \text { at end of time step (unitless). }
\end{array}
$$

The relative permeability and passability at junction $i$ are defined to be the average of the values of these variables at the two control volumes upwind and downwind of junction $\mathrm{i}$.

Applying the quadratic equation, the superficial velocity of the liquefied material at each node at the end of the time step is calculated using the equation

$$
\mathrm{j}_{\mathrm{i}}^{\mathrm{m}+1}=\frac{-\mathrm{B} \pm\left[\mathrm{B}^{2}-4 \mathrm{AC}\right]^{0.5}}{2 \mathrm{~A}}
$$

The above equation has two values. Since the liquefied material can only flow down, only the positive value is applied.

At the top junction in the debris bed, the superficial velocity is calculated by the equation

$$
\mathrm{j}_{1}=\mathrm{G} / \rho_{1}
$$


where
$\mathrm{j}_{1} \quad=\quad$ superficial velocity at top junction in debris bed $(\mathrm{m} / \mathrm{s})$,
$\mathrm{G}=\quad$ rate of melting of structure above the debris bed per unit of cross sectional area $(\mathrm{kg} / \mathrm{s}) / \mathrm{m}^{2}$.

At the bottom junction, the boundary condition corresponding with an impermeable boundary is imposed. Thus,

$$
\mathrm{j}_{\mathrm{nb}}=0.0
$$

where

$$
\mathrm{j}_{\mathrm{nb}} \quad=\quad \text { superficial velocity at bottom most junction in debris bed }(\mathrm{m} / \mathrm{s}) \text {. }
$$

Three constraints are applied to the motion of liquefied material. First, if the temperature at a location is less than the melting temperature of stainless steel, then that location is impermeable. Second, if liquid water is present at a location, then that location is impermeable. Third, if the temperature at any location is greater than the melting temperature of a mixture of $\mathrm{UO}_{2}$ and $\mathrm{ZrO}_{2}$, then that location is impermeable. In general, if the condition for the second constraint is satisfied, then the condition for the first constraint is also satisfied. The third constraint is based on the assumption that melted ( $\mathrm{U}, \mathrm{Zr}) \mathrm{O}_{2}$ will flow a small distance, freeze, and form an impermeable crust. These constraints are applied by the equation

$$
\mathrm{j}_{\mathrm{i}}^{\mathrm{m}+1}=0\left(\begin{array}{l}
\mathrm{T}_{\mathrm{i}}<\mathrm{T}_{\mathrm{ms}} \\
\mathrm{T}_{\mathrm{i}}>\mathrm{T}_{\mathrm{mu}} \\
\alpha_{\mathrm{f}}>0
\end{array}\right.
$$

where

$$
\begin{array}{lll}
\mathrm{T}_{\mathrm{i}} & = & \text { temperature at junction } \mathrm{i}, \\
\mathrm{T}_{\mathrm{ms}} & = & \text { solidus temperature of stainless steel }(1671 \mathrm{~K}), \\
\mathrm{T}_{\mathrm{mu}} & = & \text { solidus temperature of mixture of } \mathrm{UO}_{2} \text { and } \mathrm{ZrO}_{2}(\sim 3000 \mathrm{~K}), \\
\alpha_{\mathrm{f}} & = & \text { volume fraction of liquid water. }
\end{array}
$$

If a crust of frozen $(\mathrm{U}, \mathrm{Zr}) \mathrm{O}_{2}$ existed at a location before the melting of the core plate began, then that location is implicitly represented as impermeable from the assignment of a porosity of zero for that location. 
The bed saturation in each control volume at the end of the time step is then calculated using Equation (5-1) with the start of time step superficial velocities in this equation replaced with the end of time superficial velocities calculated by Equation (5-9).

The fractional difference in bed saturation between two successive iterations is calculated by the equation

$$
f_{n}=\frac{\left|S_{n}^{r+1}-S_{n}^{r}\right|}{0.5\left(S_{n}^{r+1}+S_{n}^{r}\right)}
$$

where

$$
\begin{array}{lll}
\mathrm{f}_{\mathrm{n}} & = & \text { fractional difference in value of } \mathrm{S}_{\mathrm{n}}^{\mathrm{m}+1} \text { between two successive iterations, } \\
\mathrm{r} & = & \text { iteration number, } \\
\mathrm{S}_{\mathrm{n}}^{\mathrm{r}} & = & \text { value of } \mathrm{S}_{\mathrm{n}}^{\mathrm{m}+1} \text { at } \mathrm{r} \text {-th iteration. }
\end{array}
$$

If the value of $f_{n}$ at any control volume is greater than the tolerance in error for bed saturation, another iteration is performed. The value of the tolerance in error is defined by the user; the results of a sensitivity study presented in Section 7 indicate that a value of 0.001 is appropriate.

After convergence of the debris bed saturation at each control volume has been obtained, the effect of the movement of liquefied material during the time step on heat transport is calculated. First, Equation (3-3) is used to calculate the term added to the volumetric heat generation rate for each control volume to account for the transport of liquefied material. Then, the heat conduction porosity for each control volume is updated to account for the addition or subtraction of material from each control volume during the time step. Then, the volume fractions of stainless steel and $(\mathrm{U}, \mathrm{Zr}) \mathrm{O}_{2}$ at each control volume are updated to account for the addition or subtraction of material from each control volume during the time step. The particle size at each control volume is assumed to not be influenced by the presence of liquefied debris or frozen previously liquefied debris.

The volumetric heat generation at a control volume to account for the thermal effect of the addition by flow of liquefied material to the control volume is calculated by the equation

$$
\mathrm{Q}_{\mathrm{Tn}}=-0.5\left(\mathrm{j}_{\mathrm{np}}+\mathrm{j}_{\mathrm{nm}}\right) \rho_{1} \mathrm{c}_{\mathrm{p}}\left(\mathrm{T}_{\mathrm{np}}-\mathrm{T}_{\mathrm{nm}}\right) /\left(\mathrm{y}_{\mathrm{np}}-\mathrm{y}_{\mathrm{nm}}\right)
$$

where

$$
\begin{array}{ll}
\mathrm{Q}_{\mathrm{Tn}}= & \begin{array}{l}
\text { heat transported into control volume } \mathrm{n} \text { due to movement of liquefied material } \\
\left(\mathrm{W} / \mathrm{m}^{3}\right),
\end{array} \\
\mathrm{c}_{\mathrm{p}}= & \text { heat capacity of liquefied material flowing into control volume } \mathrm{n}(\mathrm{J} / \mathrm{kg} \cdot \mathrm{K}),
\end{array}
$$




$$
\begin{array}{lll}
\mathrm{T}_{\mathrm{np}} & = & \text { temperature at downwind junction of control volume } \mathrm{n}(\mathrm{K}), \\
\mathrm{T}_{\mathrm{nm}} & = & \text { temperature at upwind junction of control volume } \mathrm{n}(\mathrm{K}) .
\end{array}
$$

Next, the calculation is made of the volume fractions of stainless steel and ( $\mathrm{U}, \mathrm{Zr}) \mathrm{O}_{2}$ at each control volume. The volume fraction of stainless steel is calculated by the equation

$\mathrm{f}_{\mathrm{sn}}=\varepsilon \mathrm{S}_{\mathrm{n}}^{\mathrm{m}+1} /\left((1-\varepsilon)+\varepsilon \mathrm{S}_{\mathrm{n}}^{\mathrm{m}+1}\right)$

where

$\mathrm{f}_{\mathrm{sn}} \quad=\quad$ volume fraction of stainless steel at control volume $\mathrm{n}$ at end of time step.

The volume fraction of $(\mathrm{U}, \mathrm{Zr}) \mathrm{O}_{2}$ is calculated by the equation

$f_{\text {un }}=(1-\varepsilon) /\left(\varepsilon S_{n}^{m+1}+(1-\varepsilon)\right)$

where

$\mathrm{f}_{\mathrm{un}} \quad=\quad$ volume fraction of $(\mathrm{U}, \mathrm{Zr}) \mathrm{O}_{2}$.

In order to estimate the rate of movement of melted stainless steel through a medium of porous debris, Equation (5-8) was solved for two representative cases. In both cases, the debris and melted stainless steel are assumed to have the characteristics and properties shown in Table 5-1. The solution was made for two values of effective saturation, namely $S_{e}=0.1$ and $S_{e}=1.0$. The substitution of these values into the equations for the coefficients in Equation (5-8) gives the results shown in Table 5-2. The superficial velocities for the two values of effective saturation are shown in Table 5-3. The superficial velocities ranged from $9.7 \times 10^{-5} \mathrm{~m} / \mathrm{s}$ to $2.9 \times 10^{-2} \mathrm{~m} / \mathrm{s}$. The table also shows the values calculated for superficial velocity when turbulent drag is neglected. For an effective saturation of 1.0, turbulent drag reduces the superficial velocity by a factor of three.

Table 5-1. Characteristics and properties for debris and melted stainless steel for scoping calculations.

\begin{tabular}{|c|c|c|c|}
\hline Characteristic or property & Symbol & Units & Value \\
\hline \hline Porosity of debris & $\varepsilon$ & - & 0.4 \\
\hline Diameter of debris particles & $D_{p}$ & $\mathrm{~m}$ & $2 \times 10^{-3}$ \\
\hline $\begin{array}{c}\text { Density of liquefied stain- } \\
\text { less steel }\end{array}$ & $\rho_{1}$ & $\mathrm{~kg} / \mathrm{m}^{3}$ & 6920 \\
\hline $\begin{array}{c}\text { Viscosity of liquefied stain- } \\
\text { less steel }\end{array}$ & $\mu_{1}$ & $\mathrm{~kg} / \mathrm{m} \cdot \mathrm{s}$ & $3.2 \times 10^{-3}$ \\
\hline
\end{tabular}


Table 5-1. Characteristics and properties for debris and melted stainless steel for scoping calculations.

\begin{tabular}{|c|c|c|c|}
\hline Characteristic or property & Symbol & Units & Value \\
\hline \hline $\begin{array}{c}\text { Wetting angle of liquefied } \\
\text { stainless steel in contact } \\
\text { with }(U, \mathrm{Zr}) \mathrm{O}_{2}\end{array}$ & $\theta$ & Degrees & 120 \\
\hline $\begin{array}{c}\text { Surface tension of liquefied } \\
\text { stainless steel }\end{array}$ & $\gamma$ & $\mathrm{N} / \mathrm{m}$ & 0.45 \\
\hline $\begin{array}{c}\text { Heat capacity of liquefied } \\
\text { stainless steel }\end{array}$ & $c_{p l}$ & $(\mathrm{~J}) / \mathrm{kg} \cdot \mathrm{K}$ & 690 \\
\hline $\begin{array}{c}\text { Thermal conductivity at } \\
\text { liquefied stainless steel }\end{array}$ & $\lambda$ & $\mathrm{W} / \mathrm{m} \cdot \mathrm{K}$ & 20 \\
\hline
\end{tabular}

Table 5-2. Values of coefficients in Equation (5-8) for two representative cases.

\begin{tabular}{|c|c|c|c|}
\hline Effective saturation & A & B & C \\
\hline \hline 0.1 & $5.67 \times 10^{10}$ & $6.77 \times 10^{8}$ & $-6.78 \times 10^{4}$ \\
\hline 1.0 & $5.67 \times 10^{7}$ & $6.77 \times 10^{5}$ & $-6.78 \times 10^{4}$ \\
\hline
\end{tabular}

Table 5-3. Superficial velocities for two representative cases.

\begin{tabular}{|c|c|c|}
\hline \multirow{2}{*}{ Effective saturation } & \multicolumn{2}{|c|}{ Superficial velocity $(\mathbf{m} / \mathbf{s})$} \\
\cline { 2 - 3 } & $\begin{array}{c}\text { Turbulent } \\
\text { drag }\end{array}$ & No turbulent drag \\
\hline \hline 0.1 & $9.7 \times 10^{-5}$ & $1.0 \times 10^{-4}$ \\
\hline 1.0 & $2.9 \times 10^{-2}$ & 0.10 \\
\hline
\end{tabular}

The relatively slow movement of the liquefied stainless steel allows the inertial terms to be neglected in the momentum equation without significant loss of accuracy. For the case of saturated debris, which results in an upper bound on the velocity of the liquefied stainless steel, the gravity and viscous terms in the momentum equation are of order of $5 \times 10^{4} \mathrm{~N} / \mathrm{m}^{3}$, while the inertial terms ${ }^{3}$ are estimated to be of order of $1 \times 10^{3} \mathrm{~N} / \mathrm{m}^{3}$.

Inclusion in the calculations of capillary forces would not significantly change the velocities shown in Table 5-3. The capillary forces are a function of the porosity and particle size of the debris, surface tension of the liquid stainless steel, and the wetting angle of liquefied stainless steel in contact with (U, $\mathrm{Zr}) \mathrm{O}_{2}{ }^{2,3}$ The values of the latter two properties are not firmly established. ${ }^{2}$ Assuming values for these latter two properties that result in an upper bound on the capillary forces, and assuming a gradient in effective saturation of $10.0 / \mathrm{m}$, the capillary force term in the momentum equation is estimated to be of order of $0.7 \times 10^{4} \mathrm{~N} / \mathrm{m}^{2}$, which is an order of magnitude smaller than the gravitational and viscous terms. 
The relatively slow movement of the liquefied stainless steel justifies the assumption of thermal equilibrium between the stainless steel and the $(\mathrm{U}, \mathrm{Zr}) \mathrm{O}_{2}$. The time constant for conduction heat transfer to the stainless steel in the interstices of the porous debris is approximated by the equation

$$
\tau=\frac{\rho_{1} c_{p l}(\Delta x)^{2}}{6 \lambda}
$$

where

$$
\begin{array}{lll}
\tau & = & \text { time constant }(\mathrm{s}), \\
\rho_{1} & = & \text { density of liquefied stainless steel }\left(6920 \mathrm{~kg} / \mathrm{m}^{3}\right), \\
c_{\mathrm{pl}} & = & \text { heat capacity of liquefied stainless steel }(690 \mathrm{~J} / \mathrm{kg} \cdot \mathrm{K}), \\
\Delta \mathrm{x} & = & \begin{array}{l}
\text { average thickness of interstices, which is estimated to be approximately equal to } \\
\text { the diameter of the } \mathrm{UO}_{2} \text { particles }\left(2 \times 10^{-3} \mathrm{~m}\right),
\end{array} \\
\lambda & = & \text { thermal conductivity of liquefied stainless steel }(20 \mathrm{~W} / \mathrm{m} \cdot \mathrm{k}) .
\end{array}
$$

The time constant for conduction heat transfer is calculated to be $0.16 \mathrm{~s}$. Assuming a maximum temperature gradient in the $(\mathrm{U}, \mathrm{Zr}) \mathrm{O}_{2}$ of $1000 \mathrm{~K} / \mathrm{m}$, liquefied stainless steel moving at a velocity of $2.9 \times 10^{-2} \mathrm{~m} / \mathrm{s}$, the debris temperature changing from $3000 \mathrm{~K}$ to $2000 \mathrm{~K}$ over a $1 \mathrm{~m}$ change in elevation, the liquefied stainless steel needs to flow for $34 \mathrm{~s}$ before experiencing a factor to two change in its ambient temperature. This order of magnitude larger time than the time constant for conduction heat transfer indicates that the assumption of thermal equilibrium of the stainless steel and $(\mathrm{U}, \mathrm{Zr}) \mathrm{O}_{2}$ is justified.

\section{Implementation into COUPLE model}

This section identifies the extensions made to the data base of the COUPLE model and to its subroutines in order to implement the numerical solution for the movement of liquefied core plate material through a porous debris bed. The variables added to the COUPLE model data base are described in Table 6-1. This table also defines the Fortran name assigned each variable added to the COUPLE data base and identifies its corresponding name in the numerical solution section of this report. The table also identifies the subroutines that calculate the values of the new variables. The arrays in Table 6-1 are stored in the 
COUPLE bulk storage array named "a," which is stored in the common block named "alcm." The pointers in Table 6-1 are stored in the COUPLE common block named "iparm."

Table 6-1. Variables added to COUPLE data base for modeling of flow of liquefied material within porous debris bed .

\begin{tabular}{|c|c|c|c|c|}
\hline Variable definition & Fortran name & $\begin{array}{l}\text { Numerical } \\
\text { solution } \\
\text { name }\end{array}$ & Units & $\begin{array}{c}\text { Subroutines } \\
\text { that } \\
\text { calculate } \\
\text { variable }\end{array}$ \\
\hline $\begin{array}{l}\text { Pointer to variable storing bed satu- } \\
\text { ration at current iteration at element } \\
n\end{array}$ & iptbst & - & - & AUMESH \\
\hline $\begin{array}{l}\text { Bed saturation at element } n \text { at current } \\
\text { iteration }\end{array}$ & $a($ iptbst $+n-1)$ & $S_{n}^{m+1}$ & - & $M O V C P L$ \\
\hline $\begin{array}{l}\text { Pointer to variable storing bed satu- } \\
\text { ration at previous iteration }\end{array}$ & iptbsO & - & - & AUMESH \\
\hline $\begin{array}{l}\text { Bed saturation at element } n \text { at previ- } \\
\text { ous iteration }\end{array}$ & $a(i p t b s 0+n-1)$ & $S_{n}^{m}$ & - & MOVCPL \\
\hline $\begin{array}{c}\text { Pointer to variable storing effective } \\
\text { bed saturation at element } n\end{array}$ & iptebs & - & - & AUMESH \\
\hline Effective bed saturation at element $n$ & $a($ iptebs $+n-1)$ & $S_{\text {en }}$ & - & $M O V C P L$ \\
\hline $\begin{array}{l}\text { Pointer to array storing Darcy perme- } \\
\text { ability at element } n\end{array}$ & iptprm & - & - & AUMESH \\
\hline Darcy permeability at element $n$ & $a($ iptprm $+n-1)$ & $k_{n}$ & $m^{2}$ & $M O V C P L$ \\
\hline $\begin{array}{l}\text { Pointer to array storing passability at } \\
\text { element } n\end{array}$ & iptpas & - & - & AUMESH \\
\hline Passability at element $n$ & $a($ iptpas $+n-1)$ & $m_{n}$ & $m$ & $M O V C P L$ \\
\hline $\begin{array}{l}\text { Pointer to variable storing relative } \\
\text { permeability at element } n\end{array}$ & iptrpr & - & - & AUMESH \\
\hline Relative permeability at element $n$ & $a($ iptrpr $+n-1)$ & $k_{l n}$ & - & $M O V C P L$ \\
\hline $\begin{array}{l}\text { Pointer to array storing mass of stain- } \\
\text { less steel in element } n\end{array}$ & iptmss & - & - & AUMESH \\
\hline Mass of stainless steel in element $n$ & $a(i p t m s s+n-1)$ & - & $k g$ & $\begin{array}{l}\text { MUPDAT, } \\
\text { MOVCPL }\end{array}$ \\
\hline $\begin{array}{l}\text { Pointer to array storing mass of }(U, \\
\qquad \mathrm{Zr}) \mathrm{O}_{2} \text { in element } n\end{array}$ & ірtтио & - & - & AUMESH \\
\hline
\end{tabular}


Table 6-1. Variables added to COUPLE data base for modeling of flow of liquefied material within porous debris bed (continued).

\begin{tabular}{|c|c|c|c|c|}
\hline Variable definition & Fortran name & $\begin{array}{l}\text { Numerical } \\
\text { solution } \\
\text { name }\end{array}$ & Units & $\begin{array}{c}\text { Subroutines } \\
\text { that } \\
\text { calculate } \\
\text { variable }\end{array}$ \\
\hline Mass of $(\mathrm{U}, \mathrm{Zr}) \mathrm{O}_{2}$ in element $n$ & $a($ iptmuo $+n-1)$ & - & $k g$ & $\begin{array}{l}\text { MUPDAT, } \\
\text { MOVCPL }\end{array}$ \\
\hline $\begin{array}{l}\text { Pointer to array storing superficial } \\
\text { velocity of liquefied material after } \\
\text { current iteration at node } n\end{array}$ & iptjlm & - & - & AUMESH \\
\hline $\begin{array}{l}\text { Superficial velocity of liquefied mate- } \\
\text { rial at end of current time step at node } \\
n\end{array}$ & $a($ iptjlm+n-1) & $\mathrm{j}_{\mathrm{n}}^{\mathrm{m}+1}$ & $m / s$ & $\begin{array}{c}M U P D A T \\
M O V C P L\end{array}$ \\
\hline $\begin{array}{l}\text { Pointer to array storing superficial } \\
\text { velocity of liquefied material after } \\
\text { previous iteration at node } n\end{array}$ & iptjlO & - & - & AUMESH \\
\hline $\begin{array}{c}\text { Superficial velocity of liquefied } \\
\text { material at start of current time step } \\
\text { at node } n\end{array}$ & $a(i p t j l 0+n-1)$ & $\mathrm{j}_{\mathrm{n}}^{\mathrm{m}}$ & $\mathrm{m} / \mathrm{s}$ & $M O V C P L$ \\
\hline
\end{tabular}

Several user-defined variables are required for the numerical solution; these variables are identified in Table 6-2. Two of the variables in Table 6-2 are material properties that are not defined in the material properties part (MATPRO) ${ }^{9}$ of SCDAP/RELAP5. These variables are the liquid-solid contact angle and the surface tension of liquefied stainless steel. When the values of these material properties are firmly established, the values will be obtained from MATPRO instead of being user-defined. Another variable in this table, namely the rate of melting of the core plate above a debris bed can be obtained from calculations performed by the core plate model in SCDAP/RELAP5. Nevertheless, it is useful to make this variable user-defined for testing and for analyses focusing on behavior of debris in the lower head of a reactor vessel instead of on behavior of an overall reactor system.

Table 6-2. User-defined variables added to data base for modeling of flow of liquefied material within porous debris bed .

\begin{tabular}{|c|c|c|c|c|}
\hline Variable definition & $\begin{array}{c}\text { Fortran } \\
\text { name }\end{array}$ & $\begin{array}{c}\text { Numerical } \\
\text { solution or } \\
\text { theory name }\end{array}$ & Units & $\begin{array}{c}\text { Common } \\
\text { block }\end{array}$ \\
\hline \hline $\begin{array}{c}\text { Liquid-solid contact angle (wetting } \\
\text { angle) }\end{array}$ & thtwet & $\theta$ & radians & tblsp \\
\hline Surface tension of liquefied material & gamwet & $\gamma$ & $\mathrm{N} / \mathrm{m}$ & $t b l s p$ \\
\hline $\begin{array}{c}\text { Rate of slumping of melting structure } \\
\text { located directly above debris bed }\end{array}$ & mdtstr & $G$ & $(\mathrm{~kg} / \mathrm{s}) / \mathrm{m}^{2}$ & $t b l s p$ \\
\hline
\end{tabular}


Table 6-2. User-defined variables added to data base for modeling of flow of liquefied material within porous debris bed (continued).

\begin{tabular}{|c|c|c|c|c|}
\hline Variable definition & $\begin{array}{c}\text { Fortran } \\
\text { name }\end{array}$ & $\begin{array}{c}\text { Numerical } \\
\text { solution or } \\
\text { theory name }\end{array}$ & Units & $\begin{array}{c}\text { Common } \\
\text { block }\end{array}$ \\
\hline \hline Accuracy of calculated bed saturation & accbst & - & - & tblsp \\
\hline
\end{tabular}

The model for calculating the movement of liquefied stainless steel was programmed in a new subroutine named MOVCPL. This new subroutine is called from subroutine COUPLE just before the call to subroutine EGEN2. The new subroutine calculates the distribution of liquefied stainless steel within the debris bed and calculates the addition or subtraction to be made to the volumetric heat generation term in the COUPLE model in order to account for the transport of heat by movement of liquefied material. The new subroutine also calculates the change in effective thermal conductivity and heat capacity at each node due to movement of liquefied material. The Fortran programming of the new subroutine is based on the numerical solution scheme outlined in Section 5 of this report.

The extensions made to existing COUPLE subroutines are summarized in Table 6-3. Subroutine STEP was extended to define input needed for the models that calculate the movement of liquefied material. Subroutine AUMESH was extended to reserve storage for the new variables added to the COUPLE model to calculate the movement of liquefied material and its consequences. Subroutine ICPL was extended to initialize the new variables added to the COUPLE model. Subroutine COUPLE was extended to call the new subroutine named MOVCPL, which calculates the movement of liquefied material and its consequences. Subroutines MAJCOU and COUPRT was extended to display the results calculated by subroutine MOVCPL.

Table 6-3. Extensions to existing COUPLE subroutines for modeling flow of liquefied material within porous debris bed .

\begin{tabular}{|c|c|l|}
\hline Subroutine & Line in subroutine & \multicolumn{1}{|c|}{ Extensions } \\
\hline \hline STEP & read(eoin,1001)dradis, ... & $\begin{array}{l}\text { After this read statement, the defini- } \\
\text { tion of input variables listed in Table } \\
(6-3) \text { is performed }\end{array}$ \\
\hline AUMESH & il11=i110+4*numel & $\begin{array}{l}\text { After this line, define pointers listed in } \\
\text { Table }(6-2) \text { and reserve storage for } \\
\text { variables associated } \text { with the pointers }\end{array}$ \\
\hline ICPL & do 50 i=1,numel & $\begin{array}{l}\text { In this do loop, initialize to zero the } \\
\text { variables in Table }(6-2) \text { with element } \\
\text { number for index }\end{array}$ \\
\hline COUPLE & call egen2(a(i8), ... & $\begin{array}{l}\text { Before this line, add call to new sub- } \\
\text { routne named MOVCPL to obtain } \\
\text { movement of liquefied material and its } \\
\text { consequences }\end{array}$ \\
\hline
\end{tabular}


Table 6-3. Extensions to existing COUPLE subroutines for modeling flow of liquefied material within porous debris bed (continued).

\begin{tabular}{|c|c|l|}
\hline Subroutine & Line in subroutine & \multicolumn{1}{c|}{ Extensions } \\
\hline \hline MAJCOU & call couprt(a(i40),... & $\begin{array}{l}\text { Extend list of arguments to include } \\
\text { values of bed saturation and porosity } \\
\text { in each element and velocity of lique- } \\
\text { fied stainless steel }\end{array}$ \\
\hline COUPRT & 100 continue & $\begin{array}{l}\text { After this line, write to output file the } \\
\text { distribution in bed saturation and in } \\
\text { the velocity of liquefied material }\end{array}$ \\
\hline
\end{tabular}

\section{Assessment}

The model for movement of liquefied material through porous debris was assessed by evaluating its calculation of the flow of melting core plate material through a porous debris bed in the lower head of a reactor vessel. The system analyzed is a system that may evolve in a LWR during a severe accident. The calculation was evaluated for reasonableness, internal consistency, and the conservation of mass and energy. The assessment is restricted to an evaluation of the fundamentals of the model because applicable experimental results are not available.

The assessment problem involved the calculation of melted core plate material falling on top of a hot debris bed composed of $\mathrm{UO}_{2}$ particles. The initial conditions and boundary conditions for the assessment problem are shown in Table 7-1. The rate of slumping of the core plate material corresponds approximately with the rate of melting caused by radiation heat transfer from the top of the debris bed to the core plate. At the bottom of the debris bed, a boundary exists that blocks the flow of liquefied material but not the conduction of heat. The outer surface of the lower head is in contact with a pool of water. At the top surface of the debris bed, the imposed boundary condition was heat transfer by radiation and convection to steam at a temperature of $1700 \mathrm{~K}$ and a pressure of $0.2 \mathrm{MPa}$. A schematic of the assessment problem is shown in Figure 7-1. The figure also shows the nodalization of the debris bed and of the lower head supporting the debris bed. The dashed lines in the figure describe the finite elements used in the numerical solution to represent the debris and lower head, and the intersection of the dashed lines are the nodes at which temperature was calculated.

Table 7-1. Initial conditions and boundary conditions for assessment problem.

\begin{tabular}{|c|c|}
\hline Characteristic & Value \\
\hline \hline Core plate material & Stainless steel \\
\hline Debris bed material & $\mathrm{UO}_{2}$ \\
\hline
\end{tabular}


Table 7-1. Initial conditions and boundary conditions for assessment problem. (continued)

\begin{tabular}{|c|c|}
\hline Characteristic & Value \\
\hline \hline Debris bed porosity & 0.4 \\
\hline Maximum depth of debris bed $(\mathrm{m})$ & 0.9 \\
\hline Initial temperature of debris bed $(\mathrm{K})$ & 2500 \\
\hline Nuclear heat generation rate in debris bed $\left(\mathrm{MW} / \mathrm{m}^{3}\right)$ & 0.70 \\
\hline Diameter of particles in debris bed $(\mathrm{mm})$ & 6 \\
\hline Rate of slumping of core plate $\left(\mathrm{kg} / \mathrm{m}^{2}\right) / \mathrm{s}$ & 10 \\
\hline Temperature of slumping core plate material at top of debris bed $(\mathrm{K})$ & 12 \\
\hline Initial temperature of lower head of reactor vessel $(\mathrm{K})$ & 400 \\
\hline Thickness of lower head $(\mathrm{m})$ & 0.158 \\
\hline Composition of lower head & Carbon steel \\
\hline Heat transfer coefficient at interface of debris and lower head $\left(\mathrm{W} / \mathrm{m}^{2} \cdot \mathrm{K}\right)$ & 500 \\
\hline
\end{tabular}

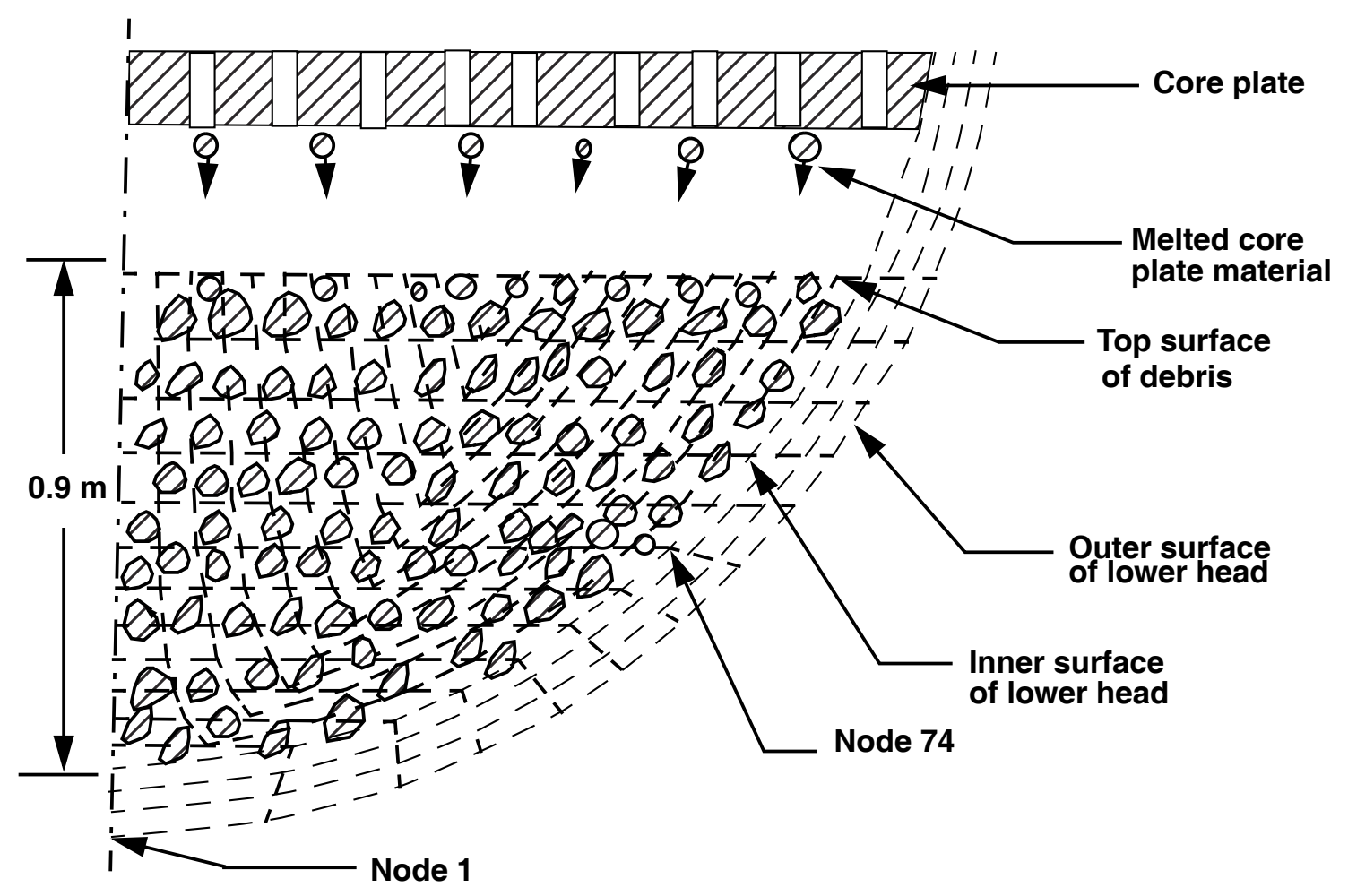

Figure 7-1. Schematic and nodalization diagram of assessment problem. 
The results of the calculations are plotted for evaluating the reasonableness of the model for calculating the movement of liquefied material through porous debris. First, a plot of the transient distribution of stainless steel in the debris bed is presented. This plot has information for evaluating the capability of the model to conserve mass. Second, a plot is presented of the transient distribution in velocity of the liquefied stainless steel permeating the porous debris. This plot presents information for evaluating the model's solution of the momentum equation for the liquefied material. Third, a plot is presented of the transient temperature distribution in the debris bed. This plot presents information for evaluating the model's capability to conserve energy.

The liquefied stainless steel is calculated to permeate through the porous debris bed rather quickly. Figure 7-2 is a plot of the axial distribution in debris bed saturation along its centerline for times after slumping of $50 \mathrm{~s}, 100 \mathrm{~s}$, and $300 \mathrm{~s}$, respectively. After $50 \mathrm{~s}$ of slumping, the stainless steel was calculated to permeate $0.7 \mathrm{~m}$ into the debris bed. After $80 \mathrm{~s}$ of slumping, some stainless steel was calculated to permeate to the bottom of the debris bed. After $300 \mathrm{~s}$, the bottom $300 \mathrm{~s}$ of the debris bed along its centerline was calculated to be saturated with stainless steel. After $550 \mathrm{~s}$, the bottom $0.7 \mathrm{~m}$ of the debris bed along its centerline was calculated to be saturated with stainless steel. The transient increase of stainless steel in the debris bed is consistent with the mass of stainless steel that slumped onto the top of the debris bed. This consistency indicates that the model for movement of liquefied material through porous debris conserves mass.

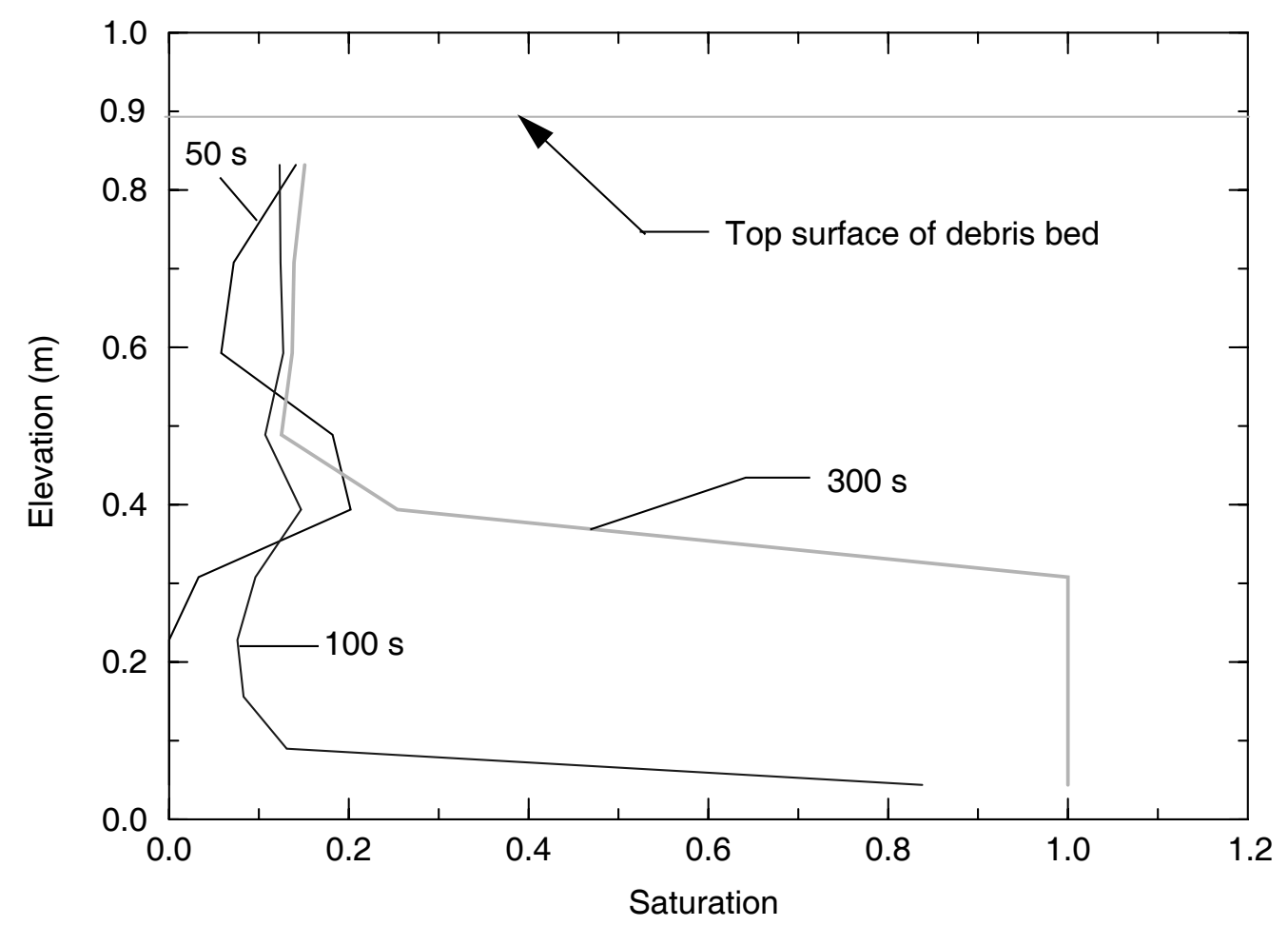

Figure 7-2. Calculated transient distribution of stainless steel in debris bed.

The liquefied stainless steel was calculated to move downward through the porous debris with a superficial velocity of about $1.5 \mathrm{~mm} / \mathrm{s}$. The actual velocity, which is the superficial velocity divided by the 
product of the porosity times the bed saturation, was calculated to be about $15 \mathrm{~mm} / \mathrm{s}$. The transient distribution in the velocity of the liquefied stainless steel along the centerline of the debris bed is plotted in Figure 7-3. The velocity calculated by the model is consistent with the hand calculations for velocity presented in Section 5 of this report. After $300 \mathrm{~s}$, the velocity is equal to zero for the elevation interval of 0.0 to $0.35 \mathrm{~m}$; the debris bed is saturated in this elevation interval and the bottom of the saturated region is an impermeable boundary.

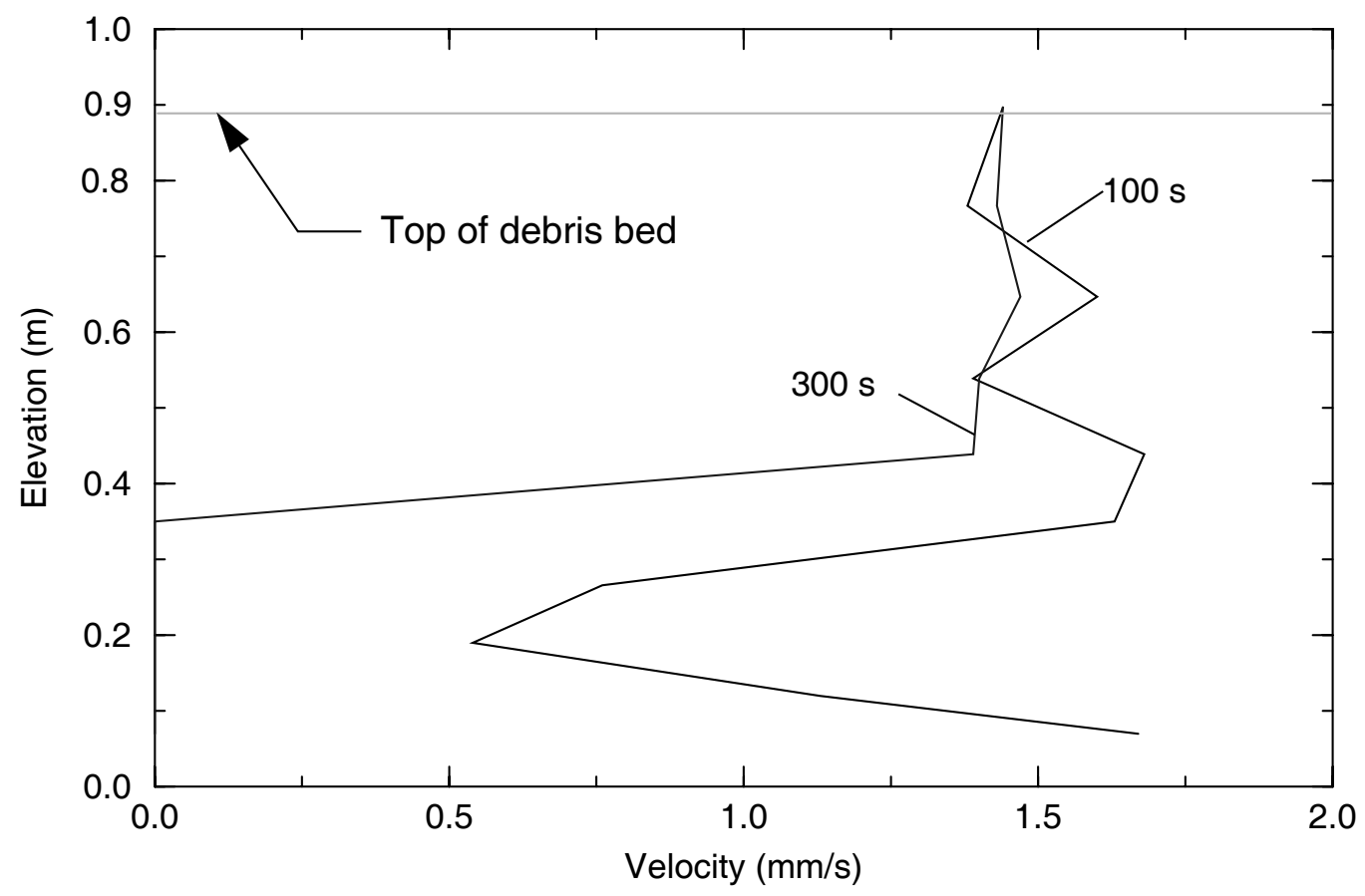

Figure 7-3. Calculated transient distribution in superficial velocity of stainless steel in debris bed.

The movement of liquefied stainless steel through a hot porous debris bed results in a cooling of the upper part of the debris bed. The transient temperature distribution in the debris bed along its centerline is plotted in Figure 7-4. At the time of $0.0 \mathrm{~s}$, the entire porous debris bed is at a temperature of $2500 \mathrm{~K}$. After $300 \mathrm{~s}$ of continuous slumping of liquefied stainless steel at a temperature of $1730 \mathrm{~K}$, the upper part of the debris bed has cooled to a temperature of $1819 \mathrm{~K}$. This cooling of the porous debris is consistent with the heat sink capacity of the stainless steel that permeated the debris bed, and thus indicates that the model is conserving energy. The cooling of the bottom part of the debris bed is due to its contact with the lower head.

The movement of liquefied stainless steel to the bottom of the debris bed results in an increase in heat transfer to the lower head supporting the debris bed. The transient temperature of the inner surface of the lower head and the bottom of the debris bed are plotted in Figure 7-5. The temperatures are plotted for the location on the inner surface that is $0.5 \mathrm{~m}$ above the point at which the lower head centerline penetrates its inner surface. Until $50 \mathrm{~s}$, the inner surface of the lower head is slowly increasing in temperature and the bottom surface of the debris is slowly decreasing in temperature. This rate of heat transfer is occurring at a slow rate because of the small rate of heat transfer across the interface between the debris and lower head. 


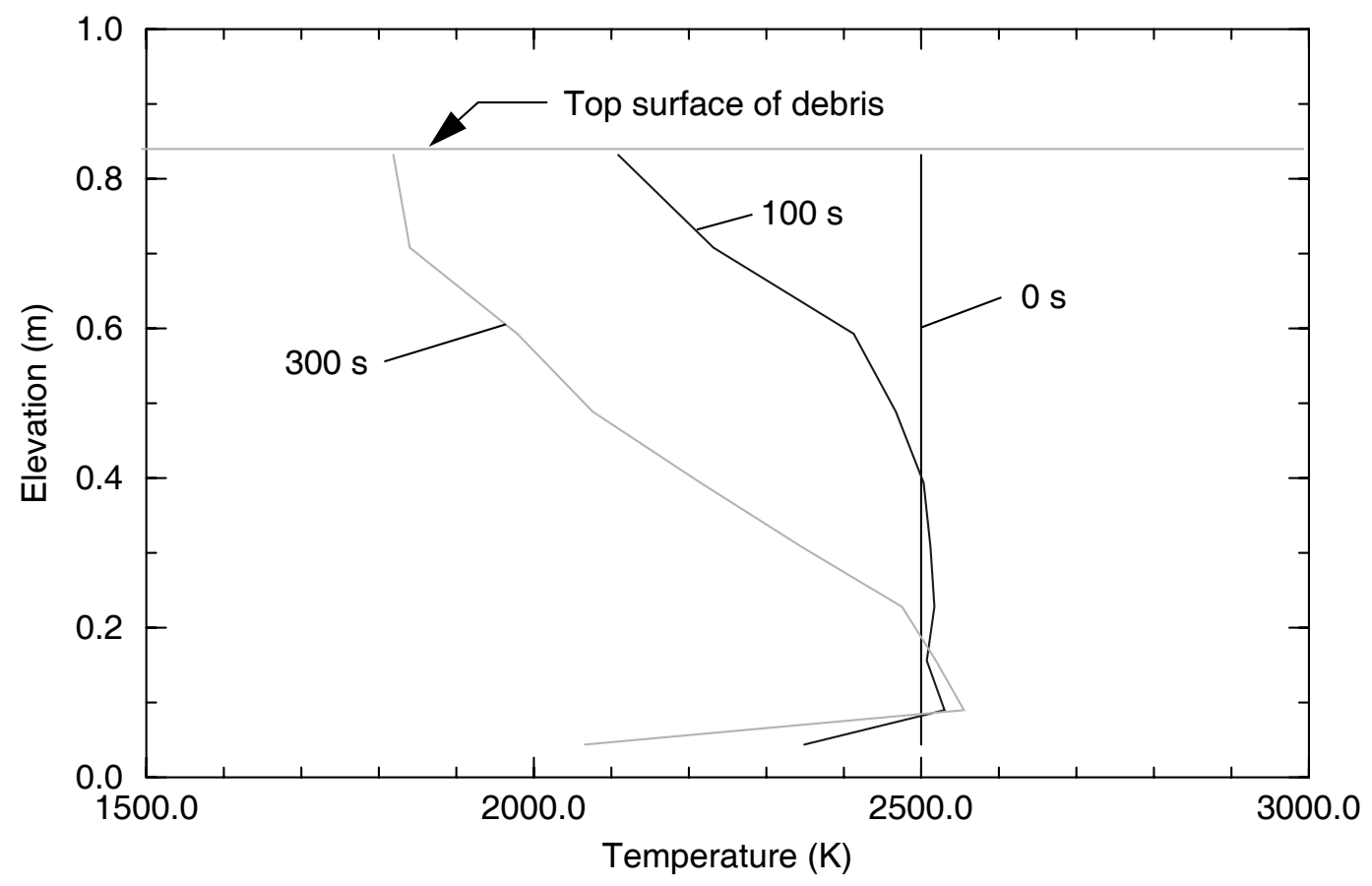

Figure 7-4. Calculated transient temperature distribution in debris bed along its centerline.

After $50 \mathrm{~s}$, stainless steel has permeated to this location and filled in the interface between the inner surface of the lower head and the bottom surface of the debris bed. The stainless steel presence results in a significant increase in the rate of heat transfer at the interface of the debris and the lower head, and as a result the inner surface temperature of the lower head increases significantly. The stainless steel presence in the debris also increases the conduction of heat through the porous debris. The calculated effective thermal conductivity for three levels of debris saturation are shown in Table 7-2. The effective thermal conductivity ranges from $2.5 \mathrm{~W} / \mathrm{m}^{2} \cdot \mathrm{K}$ for a saturation value of zero to $9.4 \mathrm{~W} / \mathrm{m}^{2} \cdot \mathrm{K}$ for fully saturated debris. This increase in thermal conductivity of the debris also increases the heat transfer rate from the interior of the debris to the lower head supporting the debris. 


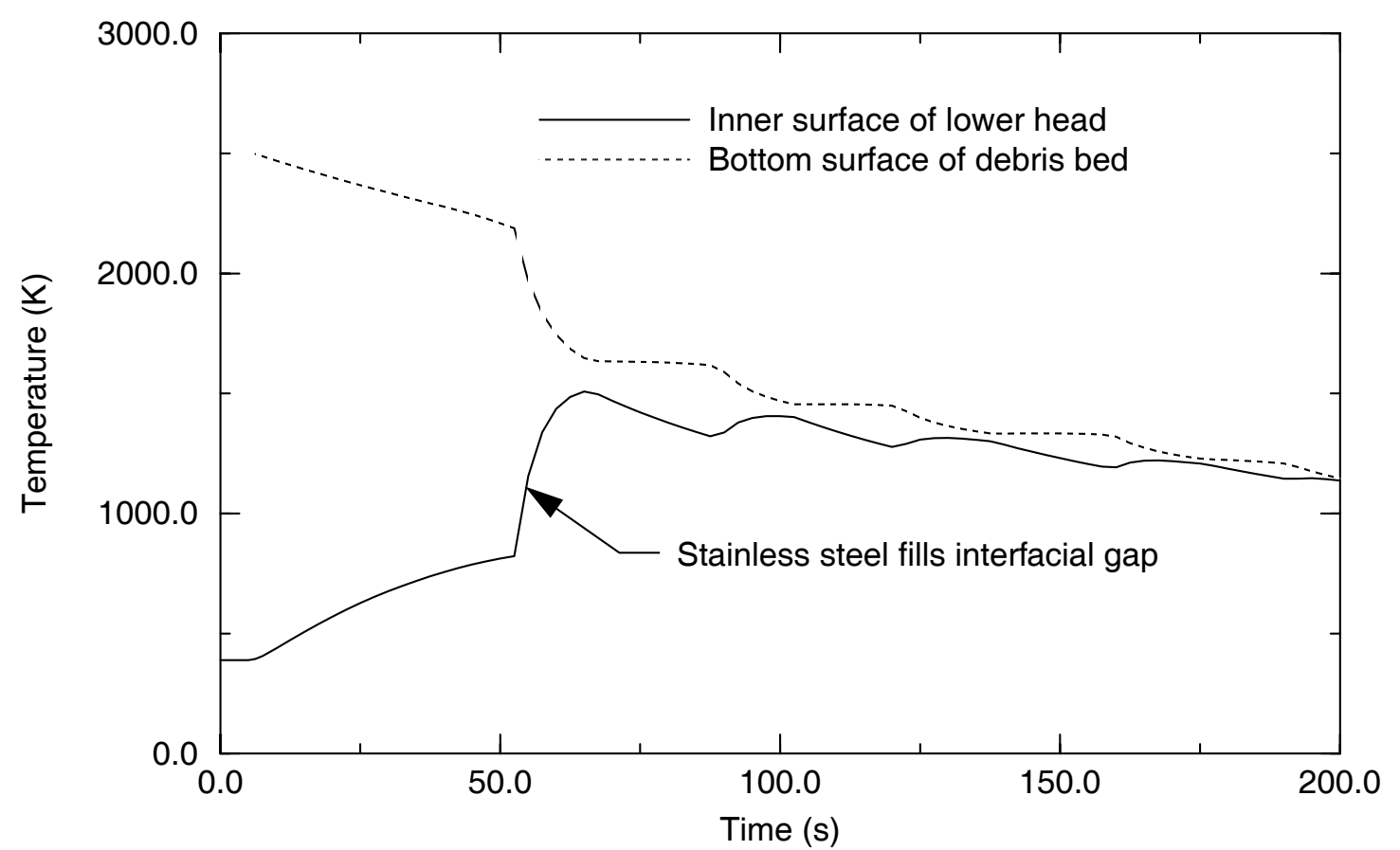

Figure 7-5. Transient temperature of inner surface of lower head at location $0.5 \mathrm{~m}$ above bottom center of lower head.

Table 7-2. Effect of level of debris saturation on thermal conductivity of debris.

\begin{tabular}{|c|c|}
\hline Level of debris saturation & $\begin{array}{c}\text { Effective thermal conductivity } \\
\left(\mathrm{W} / \mathrm{m}^{2} \cdot \mathrm{K}\right)\end{array}$ \\
\hline \hline 0.0 & 2.5 \\
\hline 0.20 & 4.7 \\
\hline 1.0 & 9.4 \\
\hline
\end{tabular}

The numerical solution was evaluated by performing calculations with three values of the error tolerance and then comparing the calculated results and the maximum number of iterations for convergence. The error tolerance is defined to be the maximum allowed fractional difference between iterations of the debris saturation at any location in the debris bed. This tolerance is defined in detail in Section 5 of this report. The base case value for the error tolerance was 0.001 and calculations were also performed for values of 0.0001 and 0.01 . The results of this sensitivity study are shown in Table 7-3. The sensitivity study showed that an error tolerance smaller than 0.001 did not significantly change the calculated results. The calculated saturation at a selected point in the debris bed for two different times was approximately the same for the two smaller values of error tolerance. The largest deviation occurred at 320 $\mathrm{s}$ after the start of slumping, when the two smaller values for the error tolerance produced almost the same results, but the value for an error tolerance of 0.01 was about $7 \%$ larger than the results with the two smaller values of the error tolerance. The study also showed that a value for the error tolerance of $0.001 \mathrm{did}$ not result in an excessive number of iterations; in general, convergence occurred in eight or less iterations. The numerical solution imposes a minimum of two iterations in order to evaluate whether convergence has 
occurred. In summary, the results shown in Table 7-3 indicate that an error tolerance of 0.001 is appropriate.

Table 7-3. Study of sensitivity of calculated results to accuracy criterion.

\begin{tabular}{|l|c|c|c|}
\hline \multirow{2}{*}{ Calculated behavior of debris bed } & \multicolumn{3}{|c|}{ Error tolerance } \\
\cline { 2 - 4 } & 0.001 & 0.0001 & 0.01 \\
\hline \hline $\begin{array}{l}\text { Time for stainless steel to permeate 0.9 } m \\
\text { into debris bed }(s)\end{array}$ & 69 & 69 & 69 \\
\hline $\begin{array}{l}\text { Bed saturation 50 s after start of slumping } \\
\text { at elevation 0.5 } m \text { below top surface }\end{array}$ & 0.2024 & 0.2027 & 0.1975 \\
\hline $\begin{array}{l}\text { Bed saturation 320 } s \text { after start of } \\
\text { slumping at elevation 0.5 } m \text { below top } \\
\text { surface }\end{array}$ & 0.5679 & 0.5606 & 0.6065 \\
\hline $\begin{array}{l}\text { Number of iterations for convergence at } \\
50 \mathrm{~s}\end{array}$ & 8 & 10 & 7 \\
\hline $\begin{array}{l}\text { Number of iterations for convergence at } \\
300 \mathrm{~s}\end{array}$ & 2 & 2 & 2 \\
\hline
\end{tabular}

A study was also performed of the change in calculated results with respect to changes in rate of slumping and the size of the debris particles. These two parameters have a large degree of uncertainty. A calculation was performed for a slumping rate of $4.0\left(\mathrm{~kg} / \mathrm{m}^{2}\right) / \mathrm{s}$ instead of the base case value of $10(\mathrm{~kg} /$ $\left.\mathrm{m}^{2}\right) / \mathrm{s}$. The former value is consistent with the rate of melting of a core plate above a debris bed with a temperature at its top surface of $2500 \mathrm{~K}$. A calculation was also performed for debris particles with a diameter of $1 \mathrm{~mm}$ instead of the base case value of $6 \mathrm{~mm}$. The former value is regarded as a lower bound value on the size of the debris particles.

The results of the study indicate that the calculated changes in debris behavior are consistent with the changes in the rate of slumping and particle size. The results are presented in Table 7-4 and in Figure 7-6. In Table 7-4, Case 1 is the base case, where the slumping rate is $10\left(\mathrm{~kg} / \mathrm{m}^{2}\right) / \mathrm{s}$ and the size of the particles is $6 \mathrm{~mm}$. For Case 2, the slumping rate is $4\left(\mathrm{~kg} / \mathrm{m}^{2}\right) / \mathrm{s}$ and the particle size is $6 \mathrm{~mm}$. For Case 3, the slumping rate is $10\left(\mathrm{~kg} / \mathrm{m}^{2}\right) / \mathrm{s}$ and the particle size is $1 \mathrm{~mm}$. The results show that a slumping rate of $4\left(\mathrm{~kg} / \mathrm{m}^{2}\right) / \mathrm{s}$ (Case 2) instead of $10\left(\mathrm{~kg} / \mathrm{m}^{2}\right) / \mathrm{s}$ (Case 1) increases from $68 \mathrm{~s}$ to $112 \mathrm{~s}$ the time for liquefied stainless steel to permeate to the bottom of a $0.9 \mathrm{~m}$ deep debris bed. A smaller slumping rate results in significantly less cooling of the top surface of the debris bed. After $200 \mathrm{~s}$ of slumping, the temperature of the top surface of the debris bed has decreased from $2500 \mathrm{~K}$ to $1981 \mathrm{~K}$ and $2323 \mathrm{~K}$ for Cases 1 and 2, respectively. A smaller rate of slumping also delays the heatup of the inner surface of the lower head, as is shown in Figure 7-6. In this figure, the temperature histories of the inner surface are shown for the three cases at a location $0.5 \mathrm{~m}$ above the bottom center of the lower head. As shown in this figure, the heatup of the inner surface occurred significantly earlier for Case 1 than for the other two cases. 
Table 7-4. Study of calculated results to rate of slumping and particle size.

\begin{tabular}{|l|c|c|c|}
\hline \multicolumn{1}{|c|}{ Calculated behavior of debris bed } & \multicolumn{3}{c|}{ Case } \\
\cline { 2 - 4 } & $\mathbf{1}$ & $\mathbf{2}$ & $\mathbf{3}$ \\
\hline \hline Time for stainless steel to permeate 0.9 m into debris bed $(\mathrm{s})$ & 68 & 112 & 185 \\
\hline $\begin{array}{l}\text { Bed saturation, 0.5 } \mathrm{m} \text { below top surface after } 200 \mathrm{~s} \text { of } \\
\text { slumping }\end{array}$ & 0.122 & 0.0109 & 0.047 \\
\hline $\begin{array}{l}\text { Actual stainless steel velocity, 0.5 m below top surface after } \\
200 \text { s of slumping }(\mathrm{mm} . / \mathrm{s})\end{array}$ & 27.7 & 15.1 & 0.73 \\
\hline $\begin{array}{l}\text { Bed saturation, 0.5 } \mathrm{m} \text { below top surface after } 400 \mathrm{~s} \text { of } \\
\text { slumping }\end{array}$ & 1.00 & 0.082 & 0.552 \\
\hline $\begin{array}{l}\text { Actual stainless steel velocity, 0.5m below top surface after } \\
\text { 400 s of slumping }(\mathrm{mm} / \mathrm{s})\end{array}$ & 0.0 & 19.0 & 10.8 \\
\hline $\begin{array}{l}\text { Temperature, 0.2 } \mathrm{m} \text { below top surface after } 200 \mathrm{~s} \text { of } \\
\text { slumping }(\mathrm{K})\end{array}$ & 1981 & 2323 & 2034 \\
\hline
\end{tabular}

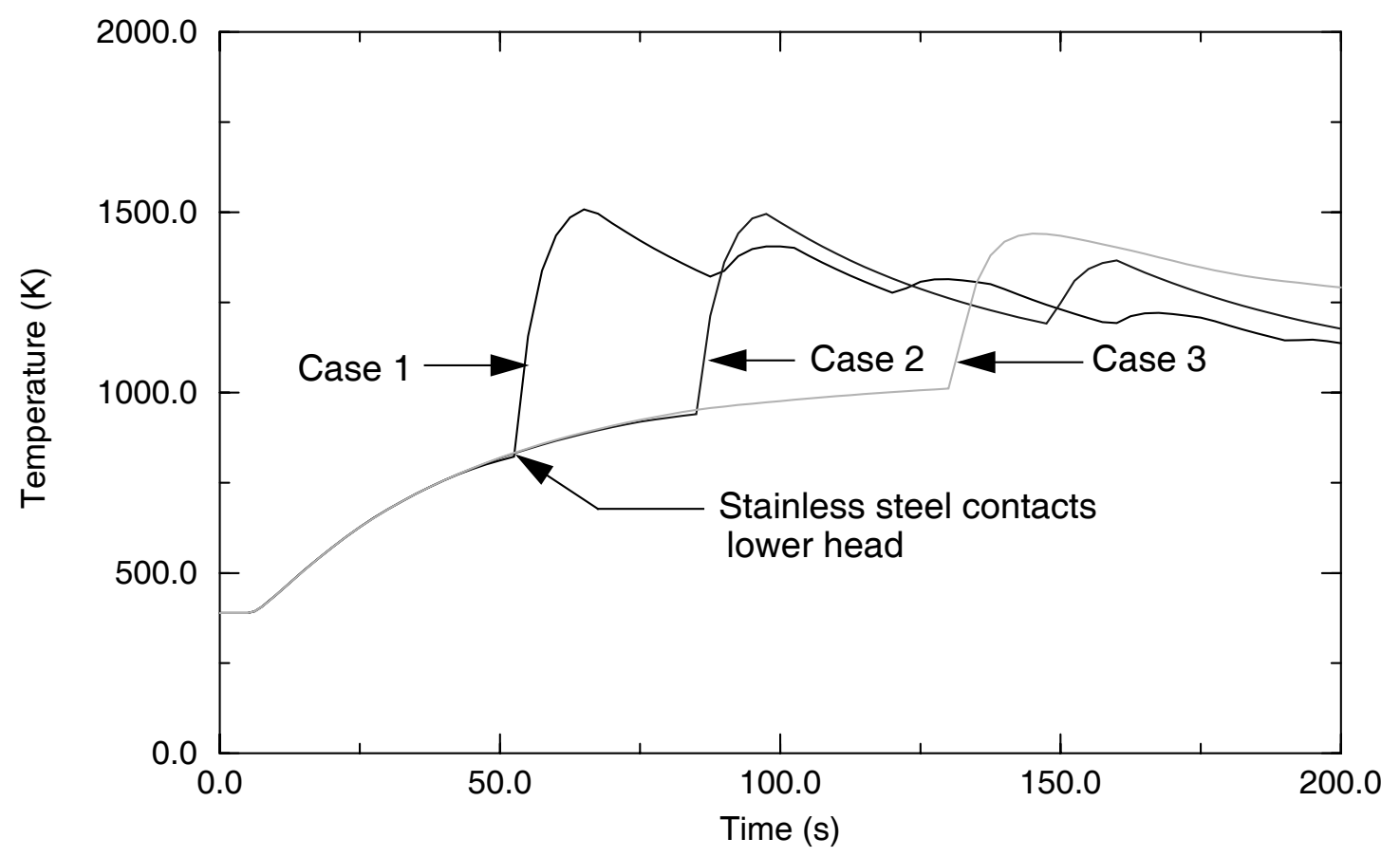

Figure 7-6. Temperature histories for three cases of inner surface of lower head at location $0.5 \mathrm{~m}$ above bottom center of lower head. 


\section{Summary and Conclusions}

A design was described of a model to calculate the movement of liquefied core plate through the interstices of porous debris composed of $(\mathrm{U}, \mathrm{Zr}) \mathrm{O}_{2}$ particles. The model was implemented into the COUPLE model in SCDAP/RELAP5 to give it the capability to calculate the effect on lower head heatup of liquefied core plate material moving through porous debris in the lower head. Equations and solution methods were presented for the calculation of the motion of liquefied material and the heat transported by the moving material. Equations were also presented for calculating the effect of moving material on the effective thermal conductivity and heat capacity of the debris it permeates. A description was presented of the extensions in Fortran programming required for implementation of the model for movement of liquefied material through porous debris into the COUPLE model. The assessment of the implemented model indicated that it satisfies the fundamental laws for heat and mass transfer. The model was applied to the analysis of a debris bed that may accrete in the lower head of a LWR during a severe accident. The analysis indicated that material from a melting core plate may permeate through a hot debris bed to the inner surface of the lower head supporting the debris. The presence of the relocated core plate material at the bottom of the debris bed increases the heat transfer from the debris to the lower head supporting the debris.

\section{References}

1. The SCDAP/RELAP5 Development Team, "SCDAP/RELAP5/MOD3.2 Code Manual, Volume 2: Damage Progression Model Theory,” NUREG/CR-6150, Volume 2, Rev. 1, INEL-96/0422, July 1998.

2. R. C. Schmidt and R. D. Gasser, "Models and Correlations of the DEBRIS Late-Phase Melt Progression Model," SAND93-3922, September 1997.

3. L. J. Siefken, "SCDAP/RELAP5 Modeling of Movement of Melted Material Through Porous Debris in Lower Head,” INEEL/EXT-98-01178, December 1998.

4. Mo Chung and Ivan Catton, "Post-Dryout Heat Transfer in a Multi-Dimensional Porous Bed," Nuclear Engineering and Design 128 (1991) pages 289-304.

5. F. B. Cheung, K. H. Hadded, and Y. C. Liu, "A Scaling Law for the Local CHF on the External Bottom Side of a Fully Submerged Reactor Vessel," NUREG/CP-0157, Vol. 2, February 1997, pp. 253-277.

6. The RELAP5 Development Team, "RELAP5 Code Manual, Models and Correlations," NUREG/CR5535, Vol. 4, August 1995.

7. S. Imura and E. Takegoski, "Effect of Gas Pressure on the Effective Thermal Conductivity of Packed Beds," Heat Transfer Japanese Research, 3, 4, 1974, p. 13.

8. D. Vortmeyer, "Radiation in PAcked Solids," 6th International Heat Transfer Conference, Toronto, Canada, 1978.

9. The SCDAP/RELAP5 Development Team, "SCDAP/RELAP5/MOD3.2 Code Manual, Volume 4: MATPRO - A Library of Materials Properties for Light-Water-Reactor Accident Analysis," NUREG/ CR-6150, Volume 4, Rev. 1, INEL-96/0422, July 1998

10. E. W. Coryell and F. P. Griffin, “SCDAP/RELAP5 Lower Core Plate Model,” INEEL/EXT-99-01029, September, 1999. 
